\title{
Лексико-типологический подход
} к анализу приставочных дериватов: глаголы падения с приставками *o-/obв русском, сербском и словенском языках

\section{Д. А. Рыжова}

Национальный исследовательский университет «Высшая школа экономики», Москва; daria.ryzhova@mail.ru

\section{М. Л. Кулешова}

Московский государственный университет им. М. В. Ломоносова, Москва; seveda@yandex.ru

Аннотация. В статье на материале глаголов падения с приставками *o-/obв русском, сербском и словенском языках разрабатывается подход к типологически ориентированному анализу значений словообразовательных приставок. На основе словарных и корпусных данных, дополненных опросами носителей, исследуются особенности употребления глаголов падения с приставками * o-/obи формируется набор значений, характерных для этой лексической группы. Мы показываем, что русские и сербские когнаты покрывают одно и то же концептуальное пространство, но по-разному распределяют его между глагольными лексемами, т. е. различия между русским и сербским языком в этой семантической области сводятся в основном к особенностям семантики корней, а не приставок. Словенская система близка к сербской с точки зрения семантики корневых морфем, однако в ней происходит смещение семантики приставок: $o$-/ob- в разных зонах вытесняется приставками $o d$-, $z$ - и $u$-. Эти закономерности мы отражаем на семантической карте, на которую, без нарушения принципа смежности, накладываются и корневые морфемы, и приставки во всех трех языках. Мы также показываем, что одинаковые метафорические употребления характерны не столько для когнатов, сколько для глаголов, покрывающих одни и те же точки концептуального пространства.

Ключевые слова: славянские приставки, приставки * $o$-/ob-, глаголы падения, семантическая карта, русский язык, словенский язык, сербский язык. 


\title{
Lexical typological approach to prefix derivatives: verbs of falling with the prefixes *o-/ob- in Russian, Serbian and Slovenian
}

\section{A. Ryzhova}

National Research University Higher School of Economics, Moscow; daria.ryzhova@mail.ru

\section{L. Kuleshova}

Lomonosov Moscow State University, Moscow; seveda@yandex.ru

\begin{abstract}
The paper presents a novel approach to a typologically oriented semantic analysis of Slavic prefixes exemplified with the data of Russian, Serbian and Slovenian verbs of falling with the prefixes $* o-/ o b$-. Based on dictionary and corpus data supplemented by native speakers surveys we scrutinize distributional properties of the verbs of falling with the prefixes $*_{o-/ o b}$ - and form a list of their meanings expressed in different contexts.

We show that Russian and Serbian cognates cover one and the same conceptual space, but the verbs partition it in different ways, i.e. the differences between Russian and Serbian within this semantic domain are mostly due to semantic properties of the verbal roots, while the prefixes exhibit a similar linguistic behavior. In Serbian, unlike Russian, the root -val- is not used in the domain of falling, and the Serbian root -padcovers almost all the situations, in which -syp- is used in Russian. Thus, cognates are not semantically equivalent to each other, for instance, the Serbian verb osuti se corresponds to Russian verbs obsypat'sya and obrushit'sya rather than to its direct cognate osypat'sya. In Slovenian, the system of the verbal roots with the meaning of falling is very close to the Serbian one (the root -val- is not present, -pad-is used broader), while the semantics of the prefixes changes: the prefixes $o d-, z$ - and $u$-drive out $o$ - $/ o b$ - in different subzones of the conceptual space.

We visualize these tendencies with a semantic map, which allows to map both roots and prefixes without any violation of the Semantic Map Connectivity Hypothesis (every linguistic means covers a connected region on a map). We also demonstrate that the verbs covering the same points on the map, and not the cognates as one could expect, develop the same metaphoric extensions. For example, the metaphor of the decrease («Less is Down») is conveyed by the Serbian verb opasti and the Slovenian verb upasti, which both denote literal level recession.
\end{abstract}

Keywords: Slavic prefixes, prefixes $*_{o-} / o b$-, verbs of falling, semantic map, Russian, Slovenian, Serbian. 


\section{1. Введение}

Фреймовый подход к лексической типологии, разрабатываемый Московской лексико-типологической группой MLexT (см. [Рахилина, Peзникова 2013]), уже не раз доказал свою состоятельность: он позволяет детально описывать лексические системы в языках мира, выделяя нетривиальные типологически релевантные закономерности лексикализации разных семантических зон. Об эффективности применения этого подхода к анализу различных пластов лексики в языках мира лишний раз свидетельствует и настоящий сборник, представляющий особенности лексикализации сложной семантической области глаголов падения в языках мира.

В этой статье, продолжая работать в парадигме фреймового подхода, мы обращаемся к теоретической проблеме, которой до сих пор почти не уделялось внимание в работах группы MLexT. B рамках фреймового подхода основной единицей анализа является слово, и в разных случаях, в зависимости от решения исследователя, словом считается либо корень, либо форма со всеми словообразовательными аффиксами. При этом однокоренные слова с разными аффиксами считаются либо одним и тем же словом, либо разными независимыми лексемами, и системным связям между семантикой корня и семантикой аффиксов внимание обычно не уделяется. Эта методологическая особенность легко объяснима: задача описания любой лексической зоны, в особенности глагольной, очень трудоемка, а дополнительный системный анализ всех словообразовательных моделей внутри этой семантической области сделал бы ее и вовсе невыполнимой.

В этой работе мы воспользуемся тем, что о закономерностях лексикализации поля падения уже многое известно (см. [Reznikova, Vyrenkova 2015], [Кузьменко, Мустакимова 2015], [Кашкин, Плешак $2015]$ и др.), и поставим перед собой задачу предложить типологически ориентированное описание дериватов глаголов падения с приставками $*$ o-/ob- в трех славянских языках (русском, сербском и словенском), сопоставив значения не только корней, но и приставок, и оценив вклад приставочных значений в семантику лексемы. По итогам анализа материала мы построим семантические карты, на которых отобразим особенности значений и корней, и приставок.

Значения и особенности употребления интересующих нас глаголов в русском, сербском и словенском языках мы изучали, в полном 
соответствии с идеологией и методологией MLexT, опираясь на материалы словарей ([MAC] для русского языка, [CXРС] и [PCКJ] для сербского, [SSKJ-2] для словенского), корпусов (Национальный корпус русского языка, словенский корпус «Gigafida», сербский корпус математического факультета Белградского университета), выдачи поисковой системы Google, а также результатов опросов носителей. Все русские примеры, которые приводятся в статье, взяты из Национального корпуса русского языка, а для сербских и словенских примеров источник в каждом случае дополнительно специфицирован.

Мы начнем с краткого обзора истории исследования семантики приставок *o-/ob- в рассматриваемых славянских языках (Раздел 2). Далее мы представим краткие очерки систем глаголов падения в русском, сербском и словенском языках и подробно опишем особенности употребления дериватов с приставками *o-/ob- от корней с семантикой падения, учитывая как буквальные, так и переносные значения приставочных глаголов (Раздель 3-5). Раздел 6 будет посвящен сопоставительному анализу рассмотренного материала. Здесь же мы сформулируем основные теоретические выводы и определим пути дальнейших исследований в этом направлении.

\section{2. Приставка(и) *o-/ob- в русском, словенском и сербском языках: история вопроса}

Различным семантическим, морфологическим и синтаксическим свойствам славянских приставок посвящено множество научных работ (см., например, обзор в [Кронгауз 1998]). Здесь мы кратко осветим лишь небольшую часть истории таких исследований, сфокусировавшись на двух основных вопросах, которые затрагиваются во всех работах, посвященных приставкам *o-/ob-:

1) являются ли эти форманты позиционными вариантами одной морфемы или двумя разными приставками (Раздел 2.1);

2) какие значения эти форманты привносят в семантику лексемы (Раздел 2.2). 


\section{1. *o-/ob- — одна приставка или две?}

По словам А. Мейе [цит. по Кронгауз 1998: 132-133], в праславянском языке *o- и $* b$ - представляли собой одно и то же слово, которое функционировало и как приставка, и как предлог. В качестве приставки распределение разных вариантов имело чисто фонетический характер: *o- встречалась перед согласными, a * $o b$ - — перед гласными и перед согласными-сонантами. Однако уже в праславянский период имелись отклонения от этого правила, появлявшиеся под влиянием морфологических и семантических факторов, см. [Толстая 2019].

Однако в работах, посвященных современным русскому, словенскому и сербскому языкам, вопрос о статусе рефлексов праславянских ${ }^{o}-/ o b-$ считается дискуссионным. Это связано с тем, что в современных славянских языках распределение соответствующих формантов уже нельзя назвать исключительно фонетическим, в частности, из-за наличия так называемых «минимальных пар» - дериватов от одного и того же корня, но с разными результирующими значениями, ср. русск. ожить-обжить.

В современной русистике «традиционно говорится о единой приставке с несколькими алломорфами» [Кронгауз 1998: 134]. Такого рода точка зрения представлена, например, в [Karcevki 1927], [Исаченко 1960], [Барыкина и др. 1989], [Кошелев 2004], [Эндерсен 2013]. В то же время грамматики и толковые словари далеки от единого мнения по данному вопросу: в [ГРЯ], [МАС] выделяется одна приставка с несколькими вариантами, а в [ГСРЛЯ], [РГ], [Ожегов 1972] — две разные приставки. И в том, и в другом случае имеют место определенные оговорки. Две разные приставки (о- и об-/обо-) выделяет и И. Б. Иткин [Иткин 2007: 85]. М. А. Кронгауз предлагает еще одно теоретическое решение, постулируя в современном русском языке «две глагольные приставки с полным совпадением набора алломорфов, но несовпадением их значимости» [Кронгауз 1998: 147]: о-(об-, обо-) и об- (обо-, о-). Такой подход основывается на семантике приставок (см. Раздел 2.2), их графической сочетаемости и статистических данных.

В словенском языкознании вопрос о статусе приставок $o$ - и $o b$ - также до конца не решен. Й. Топоришич [Тороrišič 2000: 217], П. Херрити [Herrity 2000: 208], А. Бендковска-Копчик [Będkowska-Kopczyk 2012] считают их одной приставкой, в то время как М. Шекли выделяет в современном словенском языке две омонимичные приставки $o(b)^{1}-$ и $o(b)^{2}$ [Šekli 2016: 280], характеризующиеся разными наборами значений. 
В классических грамматиках и работах по морфологии сербохорватского языка приставки о- и об- представляются как алломорфы одного аффикса - вплоть до 80-х гг. ХХ века (см. [Maretić 1899], [Leskien 1914], [Белић 1949], [Стевановић 1964], [Barić et al. 1979]). В работе Марвина Кантора [Kantor 1984], посвященной непосредственно элементам $o$ - и об-, впервые предлагается считать их разными морфемами, в том числе на основании наличия минимальных пар, ср. окопати 'окучить' vs опкопати 'окопать, обнести рвом' . Далее во всех известных нам более поздних работах (см. [Babić 1986], [Клајн 2002] и др.) эта позиция сохраняется: $o$ - и об- неизменно считаются разными морфемами с близкими, но не тождественными наборами значений. Для обвыделяется также алломорф об $a$ - с беглым - $a$-, не допускающим появления сложно произносимых консонантных кластеров.

В рамках данной работы мы для удобства считаем рефлексы формантов $* o-$ и $* b$ - во всех трех языках разными приставками, ни в коем случае не претендуя на теоретическую обоснованность этого решения для словообразовательной системы каждого из языков в целом.

\section{2. Семантика приставок *o-/ob-}

В описаниях семантики приставок *o-/ob- выделяются две основные тенденции: к поиску инвариантных значений (т. е. стремление к обобщению) и, наоборот, к максимальной дифференциации значений (т. е. стремление к определению тонких семантических различий).

Так, например, в статье А. М. Кошелева [Кошелев 2004] реализована первая стратегия. У русских о- и об-, представляющих собой, с его точки зрения, одну приставку, автор выделяет три концептуальных значения: «внешнее действие» (обойти, ограничить), «тотальное действие» (обзвонить, опустошить) и «новое качество» (образуметь, опьянеть) [Кошелев 2004: 68]. Первое значение может подразумевать как физическое (обрасти кустарниками), так и функциональное пространство действия (обрасти поправками) [там же: 76].

Словари и грамматики, напротив, являются примерами реализации второй тенденции. Так, в [ГСРЛЯ: 361-362], рассматривающей $о$ - и оботдельно, выделяются четыре значения, являющихся общими для обеих

${ }^{1}$ Однако, как указывает И. Клайн [Клајн 2002: 260], различия в значениях внутри таких пар, как правило, очень тонкие. 
приставок: 1) «направить действие вокруг чего-либо, на все стороны чего-либо»: оплавить, обсадить; 2) «направить действие мимо предмета» (непродуктивный тип): обежать, обойти; 3 ) «распространить действие на множество объектов»: опросить, объехать; 4) «довести действие до результата»: озябнуть, обучить - и два значения, характерные исключительно для об-: 1) «превзойти»: обыграть, обстрелять; 2) «причинить ущерб»: обсчитать, обделить. [ГРЯ] и [МАС], рассматривающие $о$ - и об- как одну приставку, приводят дополнительные значения этого единого форманта: «чрезмерность действия», «ошибочность действия» (в сочетании с частицей -ся), «снабжение чем-либо», «придание каких-либо свойств, становление чем-либо», «результативность» [цит. по Кронгауз 1998: 135-136].

В известных нам работах, посвященных словенским и сербским приставкам *o-/ob-, господствует тенденция к дифференциации значений соответствующих формантов. Так, М. Шекли, выделяя в современном словенском языке две омонимичные приставки $o(b)^{1}$ - и $o(b)^{2}$ - [Šekli 2016: 280], описывает их значения следующим образом. Первая из этих двух приставок $\left(o(b)^{l}-\right)$, очевидно, выделяется по семантическому принципу и выражает семантику лишения или удаления (ср. omagati 'oбессилеть', obglaviti ‘обезглавить', obupati ‘отчаяться', obrati ‘обобрать'), а также, по словам автора, может выполнять функцию образования перфектива (приводится только один пример obnemoči 'обессилеть', который также можно трактовать как имеющий отношение к лишению или удалению). Вторая приставка $o(b)^{2}$ - обладает значениями: 1) «вокруг чего-либо»: okopati 'обкопать', obleteti 'облететь'; 2) инхоативное значение при глаголах состояния: obležati 'остаться лежать', obviseti 'остаться висеть', obmolčati 'замолчать'; 3) перфективное значение: okrasti 'обокрасть', obledeti 'побледнеть', obubožati 'разориться’.

В целом же значение приставки $o(b)^{1}$ - соотносится с «причинить ущерб», выделяемым как дифференциальный семантический признак для русской об- [ГСРЛЯ: 361-362], при том что в словенском языке подобного рода значение свойственно и варианту $о$-. Интересно, что в русском языке словенским глаголам с $o(b)^{1}$ - часто соответствуют глаголы с двумя приставками $о$ - и без- (ср. обезглавить). Кроме того, приведенный в качестве примера на $o(b)^{l}$ - глагол obrati, на наш взгляд, скореe peaлизует значение, похожее на русское «распространение действия на множество объектов», или «тотальное действие» ([Кошелев 2004]). Наличие данного значения у словенской приставки подтверждается и Й. Топоришичем: obletati ‘облетать', obhoditi ‘обходить' [Toporišič 2000: 217]. 
Что касается приставки $o(b)^{2}$-, то здесь мы встречаем хорошо знакомое нам пространственное значение действия, направленного вокруг чего-либо (одна из реализаций «внешнего действия»), а также «перфективное» значение, напоминающее приобретение «нового качества» ([Кошелев 2004]). В то же время инхоативное значение не было

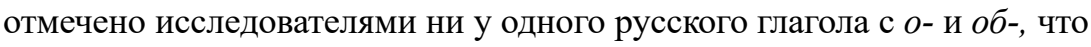
свидетельствует о том, что именно оно является существенным отличием словенской приставки $o(b)^{2}$ - от русских $о$-/oб-. Наши дополнительные исследования также показали, что для словенских приставок $o(b)^{1}$ - и $o(b)^{2}$ - нехарактерны значения ошибочности действия (ср. рус. оговориться - слов. zareči se, рус. обсчитаться - слов. ušteti se) и чрезмерности действия (ср. рус. объесться - слов. prejesti se, pус. обожраться - слов. nažreti se), реализуемые в русском языке приставкой об-.

Для сербских приставок $о$ - и об-, в современных работах считающихся скорее двумя различными формантами, И. Клайн выделяет два значения, общих для обеих приставок, а также два значения, характерных только для приставки $о$ - (см. [Клајн 2002]). Общие для обеих приставок: 1) действие на объект с разных сторон (окружсти 'окружить', описати 'описать (окружность)', опрати 'вымыть / помыть' и др.); 2) придание объекту некоторого свойства, обозначенного основой (как правило, отадъективной): осушити 'высушить', олакшати 'облегчить, ослабить', огладнети 'проголодаться', оћелавити 'облысеть'. Дополнительные значения приставки o-: 1) снабжение объекта чем-либо (осолити 'посолить', очарати 'очаровать', ограничити 'ограничить'); 2) перфективация (осудити 'осудить, обвинить', опазити 'заметить', оћутати 'умолчать; замолкнуть'). Кроме того, И. Клайн перечисляет ряд глаголов, которые не образуют отдельных групп, но и не относятся ни к одному из вышеперечисленных классов: опружити 'растянуть, расправить', осмехивати се 'улыбаться', опасти 'опасть', објавити 'объявить, опубликовать', обећати 'обещать', обрећи 'обещать' и некоторые другие. Как мы видим, в этот список попадает и интересующий нас глагол опасти 'опасть'.

Значения приставок $о$ - и об-, которые перечисляет И. Клайн, в целом близки тем, что выделяются для соответствующих приставок в русском и словенском языках. Хотя есть и отличия: например, для сербской приставки об- нехарактерно употребление в значении причинения ущерба и в связанном с ним значении совершения ошибки (ср. обмануть преварити, очибиться - погрешити, обсчитаться - прерачунати ce и т. д.). Однако сопоставление материалов трех языков очевидно 
затрудняется тем, что для описания семантики приставок не выработано единой системы значений: каждый исследователь предлагает свою классификацию, основанную на своих, особых принципах. В результате когнаты, сохранившие близкую семантику, нередко трактуются по-разному. Например, глагол опасти, который у И. Клайна оказался за пределами классификации, в терминологии А. М. Кошелева попал бы, вероятно, в класс внешнего или тотального действия (подробнее об этом см. ниже $)^{2}$. То же самое относится и к случаям употребления приставок в функции перфективизаторов, как в сербском, так и в словенском языке: возможно, более детальная классификация позволила бы и такие дериваты распределить по группам на семантических основаниях (см., например, [Janda, Lyashevskaya 2013], где высказывается идея полного отсутствия «пустых» приставок в славянских языках ${ }^{3}$ ).

Для более аккуратного сопоставления семантики приставок *o-/obв русском, словенском и сербском необходимо сплошное исследование глагольных пар и значений каждой из соответствующих лексем с последующей выработкой общей системы значений, которая уже могла бы послужить базой для сравнения материалов разных языков. Столь глобальная задача перед нами не стоит, как не ставилась она и в тех работах, которые мы здесь обсудили. Однако мы предполагаем решить ее на локальном уровне: выявить сходства и различия в употреблении этих приставок в сочетании с глагольными корнями с семантикой падения.

\section{3. Русская система глаголов падения с приставками о-/об-}

\section{1. Краткий очерк системы глаголов падения в русском языке}

Система русских глаголов падения уже освещена с разных точек зрения в нескольких работах, см. [Reznikova, Vyrenkova 2015], [Кузьменко, Мустакимова 2015] об общей типологии глаголов падения, куда

\footnotetext{
2 Отдельный вопрос, насколько эти классы в целом для сербского языка продуктивны.

${ }^{3} \mathrm{~B}$ статье рассматривается русский материал, однако теоретические выводы легко распространяются и на другие славянские языки.
} 
включен в том числе и русский материал; [Кашкин, Плешак 2015] о русских звукоподражательных глаголах падения илепнуться, грохнуться и др.; [Попкова 2019] о системе приставочных дериватов русских глаголов падения; статья О. А. Культепиной (наст. сб.) о корпусном исследовании употреблений глаголов падать / уnасть в переносном значении снижения уровня; [Наумова 2019] о метафорах русских глаголов падения. Здесь мы вкратце обсудим семантику основных глагольных основ, покрывающих зону падения в русском языке, - в той мере, в какой эти сведения понадобятся нам в дальнейшем при анализе значений дериватов с приставками о-/об-.

Доминантой поля падения в русском языке является глагол $n a d a m b^{4}$. Он употребляется очень широко и может покрывать большинство значений этой зоны: падение сверху (Ваза упала со стола), потерю вертикальной ориентации ( $В$ саду упала яблоня), падение с откреплением (Платье упало с вешалки), падение множественного субъекта (Падают листья), выпадение осадков (Падает снег). Однако для выпадения осадков этот глагол не является основным: нейтральное средство описания этой ситуации - глагол идти (ср. Идет дождь / снег / град). Для обозначения движения вниз множественного субъекта глагол $n a-$ дать используется только в том случае, если элементы однородного множества достаточно крупные (листья, плоды, камни и т. п.). Аналогичное движение сыпучих веществ передается глаголом cыnambcя. В зоне падения с откреплением падать конкурирует с целым рядом лексем из смежных семантических полей: сорваться, соскочить, слететь и др. Для обозначения падения с разрушением этот глагол практически не применяется (ср. ??Здание упало).

Глагол валиться (и большинство его приставочных дериватов) тяготеет к обозначению потери вертикальной ориентации (Машина завалилась в кювет; Несколько человек повалились на землю; валиться с ног).

Глагол рухнуть закрывает лакуну, оставленную доминантным $n a$ дать: обозначает падение с разрушением (Здание / мост / берег рухнул(o)). Кроме того, он может распространяться и на другие ситуации (потерю вертикальной ориентации: Дерево рухнуло; падение сверху: Самолет рухнул в море), привнося в них идею «разрушительности»:

\footnotetext{
4 Здесь и далее мы условно считаем одной лексической единицей глагольные формы, отличающиеся друг от друга на семантическом уровне только акциональными характеристиками (cp. naдamb vs ynacmb), и приводим для удобства только один глагол соответствующего гнезда.
} 
падения тяжелого, громоздкого объекта, обычно сопровождаемое громким звуком.

Все упомянутые выше глагольные корни свободно сочетаются с приставкой о- (опасть) или об- (обвалиться, обрушиться), причем глагол cblnambcя образует сразу два деривата: ocblnambcя и обсыnаться. Закономерности употребления этих приставочных глаголов мы и рассмотрим ниже.

Помимо перечисленных глагольных основ, в зоне падения в русском языке употребляется ряд звукоподражательных слов, профилирующих, соответственно, звуковую составляющую ситуации (ср. бухнуться, бултыхнуться, шмякнуться, шлепнуться, брякнуться, загреметь), а также разного рода разговорные формы (ср. скопытиться, навернуться и др.). Их мы оставляем за рамками нашего исследования, поскольку они не употребляются в значении движения вниз в комбина-

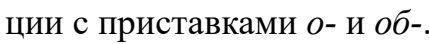

\section{2. Дериваты с приставками о-/об-}

\subsection{1. onacmb}

Русский доминантный глагольный корень -nад- в комбинации с приставкой $о$ - допускает два основных типа употреблений: (1) неконтролируемое движение вниз однородного множественного субъекта (листья опали); (2) оседание поверхности объекта (паруса опали).

Первый тип употреблений значительно более частотный, прототипический субъект такой ситуации - осенние листья. Помимо листьев, опадать могут плоды, цветы, хвоя, лепестки, т. е. обычно глагол опадать в этом значении описывает именно растения, а точнее, их сезонное обновление, т. е. ожидаемое и постепенное отпадение их сменяемых элементов, ср. (1). Элементы при этом однородные и опадают в итоге все, так что можно сказать, что здесь приставка o- отвечает, во-первых, за тотальность действия, а во-вторых, предполагает внешнее воздействие на объект, не меняя существенно его свойств (по А. М. Кошелеву, см. [Кошелев 2004]): растение избавляется от своей внешней части, которая впоследствии обновится. Второй семантический компонент реализуется особенно явно в метонимических употреблениях, где в качестве субъекта ситуации выступает само растение (ср. Клен ты мой опавший...). 
(1) Трава уже завяла, и на ней толстым, мягко и тихо шуршашим слоем лежали опавшие листья. [М. П. Арцыбашев. Жена (1905)]

Другой тип употреблений глагола опадать / опасть затрагивает объекты с обширной поверхностью, уровень которой может опуститься. В большинстве случаев в качестве такого объекта выступает ткань, наполненная воздухом: когда воздух уходит, она опадает, ср. (2). Помимо ткани, аналогичным образом может опасть вода в реке (однако в современном русском языке это значение чаще передается другим дериватом от того же корня - cnacmb). Этим же глаголом могут быть описаны части тела человека, заболевшего, постаревшего или осунувшегося. Однако все же не просто похудевшего: применение этого глагола к частям тела обязательно привносит в описание оттенок болезненности, негативной оценки ситуации, ср. (3).

(2) Высокие чинары вскипели на ветру над головой, полнясь слитно шелестящей неизвестной речью, листок с меню, в котором Олег не понимал ни слова, перепорхнул по столу, вздулась пузырем и опала скатерть, пот на лице и под мышками сделался холодным. [Евгений Чижов. Перевод с подстрочника (2012)]

(3) Было Нюре всего тридиать два, но выглядела она лет на сорок пять: в волосах седина, лицо опавщее, зубов нет и почти глухая. [Юрий Трифонов. Предварительные итоги (1970)]

Метафорических употреблений глагол опадать / опасть не развивает. В корпусе встречаются примеры, в которых он выступает в значении снижения уровня некоторого абстрактного параметра (ср. напряжение опало), но они единичны.

\subsection{2. осыпаться / обсыпаться}

Глагол сыпаться в русском языке может присоединять к себе как приставку о- (осыпаться), так и об- (обсыпаться). Согласно [MAC], обсыпаться - разговорный вариант более распространенной литературной формы осыпаться. Однако анализ корпусного материала показывает, что, хотя обсыпаться действительно значительно менее частотное, чем осыпаться (всего 94 вхождения глагола обсыпаться в НКРЯ против 1493 - глагола осыпаться), различия между ними, по-видимому, не сводятся к чисто стилистическим. 
Глагол осыпаться означает движение сыпучих веществ (и более крупных однородных объектов, таких как плоды или камни) в ситуациях нескольких типов ${ }^{5}$.

Во-первых, осыпаться может берег (склон, откос и т. п.) или реже - скала, гора. В этом случае глагол фактически обозначает падение с разрушением и конкурирует в этой области с лексемами обрушиться / обвалиться, о которых см. ниже. В отличие от обрушиться и обвалиться, осыпаться описывает постепенный процесс: объект осыпается мелкими квантами, а не обрушивается или обваливается весь разом. Кроме природных объектов, аналогичным образом могут разрушаться рукотворные конструкции, созданные, прежде всего, из глины или из камня (стена, лестница, печка, лепнина и др.).

Во-вторых, те же ситуации могут быть представлены - метонимически - с другой точки зрения: глагол осыпаться может принимать в качестве субъекта именные группы, обозначающие сами движущиеся (сыплющиеся) частицы (ср. земля, камни; краска, штукатурка, известка), а разрушающийся при этом объект может оформляться как начальная точка движения, ср. со стены осыпалась штукатурка. Отметим, правда, что в таком случае объект заведомо не разрушается полностью: действие затрагивает только его внешний слой (cp. значение

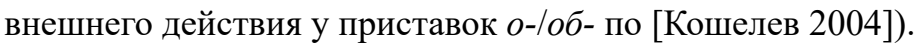

В-третьих, внешний слой может осыпаться не только у каменных конструкций и природных объектов особых типов, но и у любых других объектов, поверхность которых покрыта однородными мелкими частицами (и в этом смысле второй тип ситуаций оказывается переходным между первым и третьим): осыпается пудра с лица или с торта, шелуха от шишек и даже перья у птиц, см. (4). Отдельный класс составляют части растений: листья, зерна, лепестки, хвоя и т. д. В этой зоне осыпаться конкурирует с опасть. В общем случае осыпаться описывает более мелкие объекты (например, ягоды могут осыпаться, но не опадать, что, по-видимому, объясняется особенностями семантики глагольных корней, см. Раздел 3.1), а также может обозначать не ожидаемые сезонные, а более внезапные ситуации, свидетельствующие о нарушении обычного хода событий, см. пример (5). Как

\footnotetext{
${ }_{5}^{5}$ Сразу оговоримся, что мы не рассматриваем здесь случаи, когда глагол обозначает контролируемые ситуации, т. е. употребления глаголов осыnambcя / oбcblпаться в пассивной (ср. затем пирог осыпается пудрой) и рефлексивной (ср. жемчугом осыплюсь) конструкциях.
} 
и опасть, осыпаться может метонимически описывать и само растение, см. (6).

(4) Я была им хуже старухи галки с осыпающцимися перьями, мокрая, дрожащзая. [Галина Щербакова. Моление о Еве (2000)]

(5) Пламя вскидывается с жадным гудом и треском под нижние ветви сосны, и опаленная хвоя осыпается серыми хлопьями пепла. [Евгений Носов. И уплывают пароходы, и остаются берега (1970)]

(6) ...а посреди комнаты стояла большая мохнатая елка, прямо в лесу срубленная, совсем не похожая на дохлые осыпающиеся деревца, что продавались на московских предновогодних базаpax. [Алексей Варламов. Купавна // «Новый Мир», 2000]

Наконец, в позиции субъекта при глаголе осыпаться может оказаться конечная точка падения сыпучего вещества, см. (7). Приставка $o$ - в этом случае по-прежнему означает тотальность действия, однако теперь - по отношению к конечной точке: вся внешняя поверхность объекта оказывается равномерно покрыта сыпучим веществом.

(7) Ночь ложилась над городом, и вся необъятная, вспухшая от замерзиего снега поляна Невы, с последним отблеском солнца, осыпалась бесконечныли мириадами искр иглистого инея. [Ф. М. Достоевский. Слабое сердце (1848)]

Заметим при этом, что для глагола ocblnamscя такие употребления не очень характерны. Они выделены как особое значение в [MAC] и иногда встречаются в корпусе, но крайне редко. По-видимому, именно в этой зоне осыnamься вытесняется глаголом обсыпаться.

Лексема обсыпаться встречается в НКРЯ всего 94 раза, и абсолютно большая часть примеров относится именно к ситуации равномерного покрытия поверхности сыпучим веществом (см. (8); ср. также аналогичное облиться). Употребления во всех остальных ситуациях, характерных для осыnamься, для обсыпаться также возможны, хотя и сравнительно редки. Можно предположить, что на каком-то этапе обcblnambcя действительно был стилистическим вариантом ocblnambcя, однако на синхронном уровне четко прослеживается тенденция к дивергенции их значений.

(8) ...не умеешь красиво есть десерты - обсыпаешься и изгваздываешься. [Мария Голованивская. Я люблю тебя (1990-2000)] 
Метафорических значений глаголы осыпаться и обсыпаться не развивают.

\subsection{3. обрушиться}

Употребления глагола обрушиться можно условно разделить на два класса: 1) падение с разрушением и 2) падение сверху (с приподнятой поверхности).

В первый класс попадают такие контексты, как дом / стена / мост / берег обрушился, и от этого значения образуется типологически стандартная метафора разрушения абстрактных конструкций, см. (9).

(9) Покамест он ждал разрешения своего дела, иарская власть, по его словам, обрушилась, начальник полиции куда-то исчез, а на его месте появился новый начальник, меньщевик. [Фазиль Искандер. Бедный демагог (1969)]

Ко второму классу относятся ситуации падения крупных, тяжелых объектов с высоты, см. (10) и (11). В качестве переходных от одного класса к другому можно рассматривать ситуации падения моста или потолка: с одной стороны, они несомненно предполагают разрушение цельной конструкции, а с другой — ярко выраженное движение всей этой конструкции сверху вниз.

(10) По очуенкам специалистов, на людей обрушилось более 600 кубометров береговой породы. [Майя Кучерская. Тетя Мотя // «Знамя», 2012]

(11) Он поднялся, тычком вилки сбил со стоящей на плите жаровни крышку, с металлургическим грохотом обрушившуюся на конфорки, и полез туда. [Андрей Волос. Недвижимость (2000) // «Новый Мир», 2001]

Внутри второго класса употреблений глагола обрушиться выделяется особая группа ситуаций: внезапное начало некоторого стихийного явления (ливня, сильного снегопада, шквального ветра, цунами), см. (12).

(12) Я попробовала вздохнуть, поперхнулась, и тут посльшался шум, он все усиливался, на лицо упала одна тяжелая капля, за ней вторая, третья, и на землю обрушился ливень. [Дарья Донцова. Доллары царя Гороха (2004)] 
По-видимому, именно это значение становится источником для широко употребительной в русском языке метафоры начала абстрактного стихийного бедствия: на человека могут обрушиться несчастья, испытания, репрессии; один человек может обрушиться на другого с критикой; на город может обрушиться армия неприятеля. В большинстве случаев такие употребления характеризуются негативной окраской, однако встречаются и редкие исключения, ср. пример (13). О том, что эта метафора восходит именно к ситуации внезапного начала бури, свидетельствует множество переходных употреблений, ср. шквал критики / смерч войны / волна облавы / водопад денег обрушился на ...

(13) На начинающего дизайнера обрушился золотой дождь. [Елена Николаева. Имя для недрагоценного камня // Эксперт, 2014]

\subsection{4. обвалиться}

МАС выделяет два значения у глагола обвалиться и дает им следующие определения: 1) обрушиться, упасть; 2) осыпаться. Анализ материалов НКРЯ показывает, что в целом сфера употребления обвалиться сводится к описанию разрушения конструкций (дом, стена, колодец и др.) и природных объектов вроде берега, склона, скалы. Однако, действительно, этот глагол может обозначать разрушение двух разных типов. Во-первых, разрушение объекта целиком (или - даже чаще - существенной его части). В этой области обвалиться конкурирует с обрушиться (ср. значение 1 в [MAC]), во многих контекстах эти глаголы взаимозаменимы (ср. Во время бомбежки стена обрушилась / обвалилась). Но, по-видимому, обвалиться обычно описывает обрушение объекта под действием силы тяжести, из-за его собственной большой массы, тогда как обрушиться может и достаточно легкая конструкция под воздействием каких-то внешних причин.

Во-вторых, обвалиться описывает частичное открепление от конструкции ее внешнего слоя (штукатурки, краски, лепнины). Здесь сфера употребления обвалиться пересекается с областью использования глагола осыпаться (см. значение 2 по [MAC]). Однако обвалиться предполагает открепление более крупных фрагментов (например, пластов или кусков штукатурки) и не распространяется на другие типы потенциально сыпучих веществ (таких как пудра, сахар, части растений и проч.), которые покрывает глагол осыпаться. Возможно, в том числе потому, что такие объекты обычно не формируют пласты. 
Метафорически глагол обвалиться употребляется в значении резкого снижения абстрактного уровня, в основном в экономических контекстах, ср. (14).

(14) Очередной тревожный звонок прозвучал на прошлой неделе обвалилась гривна. Национальная валюта рухнула почти на 20 прочентов за неделю и перешла психологический рубеж в 30 гривен за доллар, что вызвало панику у населения и истерику y политиков. [Павел Шеремет. Дожить до транша // «Огонек», 2015]

Таким образом, русские глаголы падения с приставками о-/об- покрывают следующий набор физических значений:

1. Оседание поверхности объекта (далее условно «вода»)

2. Сезонное избавление растений от листвы, плодов и под. (условно «листья»)

3. Неожиданную потерю растениями листвы, плодов и более мелких элементов (ягод, пыльцы, условно «ягоды»)

4. Обрушение природных объектов («берег»)

5. Обрушение рукотворных конструкций («стена»)

6. Осыпание внешнего слоя объекта («штукатурка»)

7. Равномерное покрытие поверхности сыпучим веществом («поверхность»)

8. Падение тяжелого объекта сверху («тяжелое сверху»)

9. Внезапное начало стихии («ливень»).

Некоторые из них становятся источниками метафорических сдвигов: значение 5 («стена») порождает метафоры обрушения абстрактных конструкций, а также резкого снижения уровня некоторого абстрактного параметра; значение 9 («ливень») — метафору начала абстрактной стихии.

Все эти ситуации объединяет идея тотальности действия, привносимая приставками о-/об-. Для значений $2,3,6,7$ (и, возможно, 1) характерна также семантика внешнего действия: в ситуации затрагивается, прежде всего, внешняя часть объекта. Заметим при этом, что глагольные корни в большинстве случаев сохраняют свои семантические особенности: -naд- может обозначать движение вниз множественных субъектов, но только относительно крупных, и это ограничение сохраняется у опасть; корень -рyx- по-прежнему используется в зоне падения с разрушением, а в ситуации падения сверху 
описывает только тяжелые объекты; -cbln- описывает движение сыпучих веществ и мелких однородных объектов. Исключение составляет только корень -вал-, теряющий привязку к ситуациям потери вертикальной ориентации, по-видимому, не совместимым с семантикой приставок $о$-/об-.

\section{4. Сербская система глаголов падения с приставками о-/об-}

\section{1. Краткий очерк системы глаголов падения в сербском языке}

Основу системы сербских глаголов падения составляют когнаты русских лексем: падати 'падать', сипати се 'сыпаться' (а также 'литься'), рушити се ('рушиться'). Однако употребляются они, как и ожидалось, несколько иначе, чем их русские эквиваленты.

Глагол падати является доминантным: он может использоваться для описания большинства ситуаций падения. Падение с одной горизонтальной плоскости на другую и потеря вертикальной ориентации передаются бесприставочными формами этого глагола (Јабука мy је пала на главу 'Яблоко упало ему на голову', Дрво је пало 'Дерево упало’). Однако приставочные дериваты этого глагола тоже широко употребимы, и некоторые специальные типы падения описываются исключительно приставочными формами глагола падати. Так, например, выпадение из контейнера маркируется глаголом испадати / испасти (ср. русск. выласть), и наоборот, попадание в контейнер или вещество передается с помощью глагола упадати / уnасти, см. (15). Заметим, что в русском языке в таких контекстах используется бесприставочная форма несовершенного вида падать или общий перфективный глагол ynacms, а не более специализированный впасть, который в современном русском языке употребляется только в метафорических контекстах, ср. впасть в депрессию, но не *впасть в яму.

Ситуация проваливания опорной поверхности, а также - метонимически - падения находящихся на ней объектов передается глаголом пропадати / пропасти (ср. русск. провалиться - с другим корнем, но с той же приставкой). 
(15) Покушао је да скрене али ауто је упао у јарак.

'Он попытался повернуть, но машина завалилась (букв. 'впала') в канаву'. [носитель] ${ }^{6}$

(16) Idu jedan za drugim na većem rastojanju, tako da, ako jedan propadne kroz led da drugi može otrčati po pomoć. ${ }^{7}$

'Идут один за другим на довольно большом расстоянии, чтобы, если один провалится под лед, второй мог бы сбегать за помощью'. [www.rts.rs (15.09.2009.). Beograd (Takovska 10): Radio Televizija Srbije, 2009]

Падение с откреплением также может покрываться доминантным глаголом naдати, но в таких случаях к нему присоединяются приставки $c$ - или om-, см. (17). Однако, как и в русском языке, в сербском есть целый ряд глаголов из смежных семантических областей, которые обычно используются в ситуациях падения объекта с фокусом на его откреплении от начальной точки вместо доминантной лексемы, ср. откачити се 'отцепиться', одлетети 'отлететь', слетети 'слететь', склизнути 'соскользнуть', одвалити се 'отвалиться'. Отметим, что все они оформляются теми же приставками, что и доминантный глагол в этом значении.

(17) U pižami sam, jedno mi dugme otpalo, vrtim beli konac kojim je bilo prišiveno.

' $Я$ в пижаме, одна пуговица у меня отвалилась, кручу в руках белую нитку, которой она была пришита'. [Isaković, Antonije. Tren 2: kazivanja Čeperku. Beograd: Prosveta, 1983. P. 7-214; 224-241]

(18) Прстен јој је био превелик и спао је /склизнуо је са прста. 'Кольцо было ей велико и соскользнуло с пальца'. [носитель]

Доминантный глагол падати является и самым нейтральным средством описания движения осадков: Пада киша / снег 'Идет дождь / снег'. Помимо него, в этой зоне используется ряд глагольных лексем с более узким значением: пљуштати 'лить, хлестать' (ср. пљусак 'ливень'),

6 Здесь и далее мы обозначаем таким образом примеры, полученные в ходе элицитации.

7 Принимая в целом кириллическую форму записи сербских слов и морфем, мы сохраняем латинскую орфографию в примерах из корпуса. 
росити 'выпадать (о росе)'/ 'идти (о дожде)', а также сипати 'сыпать', подробнее о котором см. ниже.

Для описания падения с разрушением (падение зданий, мостов; обрушение конструкций или берега реки) используется возвратный глагол рушити се с различными приставками, см. (19). Приставочный дериват срушити се используется в основном в случаях полного разрушения объекта, урушити се - частичного. В ряде случаев употребляется также глагол обрушити се, которому мы уделим больше внимания в следующем разделе.

Заметим, однако, что употребление приставочных дериватов глагола рушити се не ограничивается контекстами прототипического падения с разрушением: они также могут использоваться для описания падения человека или некоторого тяжелого объекта сверху вниз, см. (20) и (21), что сближает их с русским глаголом рухнуть.

(19) U gustom dimu, u oblaku krečne prašine sruši se jedan ugao.

'В густом дыму, в облаке известковой пыли обрушился один угол'. [Šolohov, Mihail. Tihi don II. Beograd: Prosveta, 1974 (Novi Sad: Budućnost)]

(20) I ne jauknuvši, sruši se ona na zemlju.

'И не вскрикнув, она рухнула на землю'. [Po, Edgar Alan. Crna mačka. 1843]

(21) ...i vaza sa žutim krinovima što je stajala na polici srušila se.

'...И ваза с желтыми лилиями, которая стояла на полке, рухнула'. [David, Filip. San o ljubavi i smrti. Beograd: Laguna, 2008]

Наконец, для описания движения вниз сыпучих веществ и жидкостей используется глагол сипати се 'сыпаться / литься', см. (22), (23). Подчеркнем, что способность описывать не только сыпучие вещества, но и жидкости, отличает его от русского и словенского когнатов. Для описания движения вниз тонкой струйкой (опять же, и жидкостей, и мелких сыпучих веществ) используется также глагол иурити.

(22) Nervozno škljocaju upaljači, lome se drvca šibica, stolice škripe, $u$ već pune čaše sipa se voda.

'Нервно щелкают зажигалки, ломаются древки спичек, стулья скрипят, в уже полные стаканы льется вода'. [Pekić, Borislav. Besnilo. Beograd: BIGZ, 1987] 
(23) Dakle, u činiju za mućenje stave se jagode, sipa se ista takva čaša puna šećera $i$ belance od jednog krupnog jajeta ili dva belanca od manjih.

'Итак, в миску для взбивания кладется клубника, насыпается точно такой же полный стакан сахара и добавляется белок из одного крупного яйца или два белка из яиц поменьше'. [Politika (18.05.2009.). Beograd (Makedonska 29)]

Помимо основных лексических средств, обслуживающих семантическую зону падения, в сербском языке выделяется целый ряд периферийных глаголов, из которых большая часть - экспрессивные, сленговые слова, ср. стропоштати се / стрмекнути се / љоснути 'свалиться, шлепнуться, грохнуться'; стрмоглавити се 'упасть кубарем, стремглав, головой вниз' и др. Используются для описания падения и глаголы из других семантических областей: звука (треснути 'хлопнуть', звекнути 'звякнуть') или движения с вращением (скотрљати се / откотрљати се - от глагола котрљати 'катиться'). Интересно, что глагол валити се, также восходящий к семантике 'катиться', в сербском языке сохраняет более тесную связь со своим исходным значением и используется в зоне падения значительно уже, чем его русский когнат (ср. примеры выше).

\section{2. Дериваты с приставками о-/об-}

Приставки o-/об- используются в сербской системе глаголов падения достаточно широко. Они могут присоединяться ко всем основным глагольным корням зоны падения: -nad-, -cun- и -pyx-. Полученные таким образом дериваты покрывают большое количество значений в рассматриваемой семантической области. Ниже мы подробнее опишем особенности употребления каждого из дериватов.

\subsection{1. опасти}

Присоединение приставки о- к доминантному глаголу дает дериват со значительно более широкой семантикой, чем у его русского когната. Как и русский глагол опасть, он описывает ситуации сезонного опадения листвы и других частей растений (пример (24)), а также оседание поверхности объекта (25). Кроме того, он является основным средством 
описания падения более мелких объектов, таких как лепестки, ягоды и даже штукатурка (26), которые в русскоязычных текстах обычно описываются с помощью глагола осыпаться, а не опадать. Примечательно, что этот же глагол используется для описания выпадения волос (наряду с глаголом отпасти; см. (27)), т. е. в сербском языке при описании этой ситуации может профилироваться движение вниз множества однородных объектов (волосы, как и листья, «опадают»), а не момент открепления каждого из них от начальной точки (ср. русск. выпасть).

(24) leto prođe i lišće žuto opada.

'Лето проходит, и желтые листья опадают'. [Crnjanski, Miloš. Seobe druga knjiga. Antologija srpske književnosti, Učiteljski fakultet]

(25) ...koji se spuštaju ili podižu kako Sava opada ili raste.

‘...Которые [плоты] опускаются или поднимаются, по мере того как уровень воды в Саве опускается или растет (букв.: 'Сава падает или растет'). [Kuzmanović, Rade. Odmor. Beograd: autor, 1990]

(26) Farba na tom kubetu počela je bila da se krnji i ljušti, i da opada.

'Краска на том куполе начала трескаться, шелушиться и осыпаться'. [Crnjanski, Miloš. Seobe druga knjiga. Antologija srpske književnosti, Učiteljski fakultet]

(27) Vodom u kojoj je skuvano lišće trešnje, jagode i ljubičice ispiraju glavu oni kojima opada kosa.

'Отваром из листьев черешни, клубники и фиалки промывают голову те, у кого выпадают волосы'. [Čajkanović, Veselin. Rečnik srpskih narodnih verovanja o biljkama. Antologija srpske književnosti, Učiteljski fakultet]

Таким образом, в наборе значений глагола опасти можно выделить две семантические доминанты, соотносимые с двумя типами употреблений русского опасть (см. Раздел 3.2): 1) единовременное падение множества однородных объектов (листьев, лепестков, волос, кусочков краски / штукатурки); 2) уменьшение размера объемного объекта, а точнее, снижение уровня его поверхности (снижение уровня воды в реке). В отличие от своего русского когната, опасти широко употребляется и в метафорическом значении уменьшения количества или степени интенсивности, см. (28) и (29). В этом случае опасти реализует 
классическую метафору «Less is Down» в терминологии Дж. Лакоффа и М. Джонсона см. [Lakoff, Johnson 1980], и восходит это значение, по-видимому, к семантике снижения уровня поверхности.

(28) Svake sekunde osećao je kako mu samopouzdanje opada.

'Каждую секунду он ощущал, как его самоуверенность падает'. [Braun, Den. Da Vinčijev kod. ASPAC]

(29) Procenat nezadovoljnih politikom aktuelnog predsednika je opao na 54 odsto.

'Процент недовольных политикой действующего президента упал до 54\%’. [www.rts.rs (15.06.2009.). Beograd (Takovska 10) : Radio Televizija Srbije, 2009]

\subsection{2. обрушити се}

Возвратный глагол обрушити се характеризуется достаточно широким спектром значений, соотносимых с типами употреблений его русского когната обрушиться. Прежде всего, он может использоваться для описания обрушения конструкций или берега реки, см. (30). Это значение предсказуемо дает метафору разрушения абстрактной конструкции - империи, планов, политического режима (31).

(30) Bunar se obruši i posta obična bara, smrdljiva i zelena od žabokrečine. 'Колодец обрушился и стал обычной лужей, вонючей и зеленой от тины'. [Stevanović, Vidosav. Zmijsko vreme]

(31) Njemu se celokupno pravoslavlje i hrišćanski svet raduju, obrušio se jedan autokratski režim, možda poslednji, kakvih je u proteklom veku bilo mnogo.

'Ему радуется весь православный и христианский мир, рухнул один автократический режим, возможно, последний, коих в прошедшем веке было много'. [Politikini kulturni dodaci (2000)]

Далее, как и русский обрушиться, сербский обрушити се может описывать падение сверху вниз достаточно тяжелого предмета с большой высоты, которое влечет за собой разрушение падающего объекта или несет опасность для того, на кого этот объект приземлится, см. (32). Характерно для этого глагола и значение внезапного начала стихийного бедствия, см. (33). 
(32) ...ali kad je skočio na noge veliki kamen se obruši upravo na mesto gde je dotle spavao.

‘...Но когда он вскочил на ноги, большой камень рухнул как раз на то место, где он только что спал'. [Braun, Den. Da Vinčijev kod. ASPAC]

(33) Uragan «Din» obrušio se juče na karipsku obalu Meksika.

'Ураган «Дин» вчера обрушился на карибское побережье Мексики'. [Politika (22.08.2007). Beograd (Makedonska 29)]

Наконец, глагол обрушити се формирует еще одно метафорическое значение, созвучное характерной для русского обрушиться метафоре начала абстрактного стихийного бедствия (ср. обрушился на меня с критикой). У сербского глагола спектр таких употреблений даже шире, и все они объединяются семантикой нападения. Так, этим глаголом может быть описано как буквальное, физическое нападение, например, хищного зверя на свою жертву (34), так и абстрактная, психологическая атака (35), ср. русск. напасть, а также кинуться, накинуться, броситься, наброситься). Кроме того, этот же глагол может быть употреблен в ситуации, когда голодный человек набрасывается на еду (36).

(34) U jednom skoku obruši se na zver, raskide joj oštrim zubima grudi i iskopa srce.

'Одним прыжком он накинулся на зверя, разорвал ему острыми зубами грудь и выцарапал сердце'. [David, Filip. Hodočasnici neba i zemlje. Beograd: Rad, 2000]

(35) Bio je to povod da se brojni kritičari obruše na predsednika, njegovu administraciju i Republikansku stranku zbog spore obnove uništenog grada.

'Для многочисленных критиков это был повод обрушиться на президента, его администрацию и Республиканскую партию из-за медленного восстановления уничтоженного города'. [Politika (02.09.2007). Beograd (Makedonska 29)]

(36) ... a onda se obrušio na ostatke pomfrita i ribe što sam mu ih bio ostavio sinoć.

'...А потом он набросился на остатки картошки фри и рыбы, которые я оставил ему вчера вечером'. [Grifits, Nil. Patrljak. Beograd: Fabrika knjiga, 2006] 


\subsection{3. осути (се) / обасути}

От основы -сути (CB) / -сипати (НСB) в сербском языке образуется два деривата: один с приставкой $о$ - (осути), второй с приставкой об- (обасути). На первый взгляд, эта картина параллельна той, что мы наблюдали в русском языке, однако при ближайшем рассмотрении обнаруживается ряд существенных отличий.

Глаголы осути и обасути имеют некоторые пересечения в употреблениях, но в целом используются по-разному. И, что интересно, почти не конкурируют с глаголом опасти.

Глагол обасути используется в переходных конструкциях для обозначения каузативного движения жидкостей и сыпучих веществ, направленного на обильное покрытие ими некоторого объекта (37). В возвратной форме он не употребляется и к полю падения, строго говоря, не относится.

(37) U tom trenutku su ih svi bogovi obasuli cvećem $^{8}$.

'В тот миг все боги осыпали их цветами'.

Глагол осути имеет возвратную и невозвратную форму, причем в невозвратной форме он может употребляться как переходно, так и непереходно. Его переходные употребления нас интересовать не будут: в этих случаях значения глагола осути, как и обасути, выходят за рамки семантики падения (ср. русск. переходное осыпать). В непереходной конструкции невозвратный глагол осути используется для передачи значения внезапного начала сильного дождя, см. (38). Заметим, однако, что в этом же значении может употребляться и возвратная форма осути се, см. (39).

(38) Ubrzo osu jak pljusak.

'Вскоре полил сильный ливень'. [Vern, Žil. Pet nedelja u balonu. Beograd: "Jugoslavija", 1976]

(39) Док су литије обилазиле око храма, осуо се велики пьусак9. 'Пока участники литии ходили вокруг храма, полил сильный дождь'.

Возвратный глагол осути се употребляется в ситуациях, почти не пересекающихся с теми, что покрывает глагол опасти. Чаще всего

\footnotetext{
8 [https://www.facebook.com/karunareikicentar/]

9 [https://www.caglas.rs/]
} 
он обозначает ситуации покрытия поверхности мелкими объектами, обычно - кожи прыщами или сыпью, см. (40). В таких употреблениях идея движения практически не сохраняется: на первое место выходит семантика результирующего состояния, что напоминает особенности значения русского глагола обсыпаться - с тем же корнем, но с приставкой об-, а не $o$-.

Кроме того, глагол осути се может употребляться и в ситуациях внезапного неконтролируемого движения вниз множественного субъекта без акцента на равномерном покрытии поверхности, выступающей в качестве конечной точки, но при этом элементами падающего объекта нередко оказываются достаточно крупные и тяжелые предметы, что сближает его скорее с русским глаголом обрушиться, чем с когнатом осыпаться, см. (41).

(40) ... a po njegovom širokom čelu i po celom licu osule se crvene ospe. '.... ег его широкий лоб и все лицо покрылось красной сыпью'. [Edgar Alan Po. Maska crvene smrti]

(41) Kad se njegove lađe približiše kulama koje su branile ulaz u pristaništa, osu se na njih grad teških i oštrih brvana koji probiše bokove $i$ dno lađa i potopiše ih na dno mora.

'Когда его корабли приблизились к башням, защищавшим вход в порты, на них обрушился град тяжелых и острых бревен, который пробил корабли сбоку и снизу и погрузил их на морское дно'. [Milanković, Milutin. Kroz carstvo nauka. Antologija srpske književnosti, Učiteljski fakultet]

Таким образом, сербские глаголы падения с приставками о-/обв целом покрывают то же пространство значений, что и их русские когнаты, но заполняют его несколько иным образом. Глаголы опасти и обрушити се во многом параллельны своим русским когнатам, однако опасти дополнительно охватывает зону движения вниз однородных мелких элементов и сыпучих веществ (значение «ягоды»), которая в русском языке обслуживается глаголом осыпаться. При этом сербский глагол осути се семантически «смещен» относительно своего русского когната. В одной части своих употреблений он сближается скорее с русским обсыпаться, а в другой соотносится с русским обрушиться, обозначая внезапное движение вниз большого количества достаточно тяжелых объектов, что очень близко к значению, которое мы обозначили выше как «тяжелое сверху». Когнат русского глагола обвалиться в сербском языке не сохранился, хотя его еще можно встретить 
в словарях, где ему приписываются значения «свалиться, повалиться, обвалиться; низвергнуться» (см. СХРС).

\section{5. Словенская система глаголов падения с приставками o-/ob-}

\section{1. Краткий очерк системы глаголов падения в словенском языке}

Система глаголов падения в современном словенском языке подробно описана в статье [Кулешова 2016]. Здесь мы коротко изложим основные выводы, к которым мы пришли в вышеупомянутой работе.

Доминантный глагол pasti / padati почти полностью покрывает сферу употребления русского когната падать, однако включает в себя выпадение из контейнера (43) и исключает ситуацию потери вертикальной ориентации, которая описывается глаголом prevrniti se (44) [там же: 192]:

(43) Številni predmeti so padli iz torbe.

'Многие предметы выпали из сумки'. [носитель]

(44) Mizica se je prevrnila(*padla) in vse, kar je bilo na njej, je padlo po tleh. 'Столик упал (опрокинулся), и все, что было на нем, упало на пол'. [носитель]

При этом выпадение кодируется также префиксальным дериватом izpasti, который, однако, используется реже, чем доминантный глагол. От pasti образованы также глаголы odpasti, сочетающийся с совокупностями и отваливающимися частями, и zapasti, обозначающий выпадение снега.

Разнообразие словенских глаголов падения достигается главным образом за счет обилия лексем с различными корнями, специализирующихся на описании довольно узких типов ситуаций: выпадения снега (snežiti), дождя (deževati), мелкого дождя (rositi, pršiti), падения жидкостей в виде потока (liti), капель (kaniti, kapljati) и т. д. В число глаголов, обозначающих падение сыпучих веществ и совокупностей, наряду с производными от suti / sipati se 'сыпаться', которые подробно рассматриваются далее, входит также krušiti se, отвечающий за падение камней и осыпающейся штукатурки, см. (45), или другого распадающегося материала [там же: 194]: 
(45) Šolsko poslopje je bilo že nevarno, saj so s strehe padale opeke, krušil se je omet.

'Здание школы было уже небезопасным, так как с крыши падали кирпичи, штукатурка обваливалась'. [Delo, 2007]

В словенском языке существует разветвленная система глаголов падения, связанная со скользкими поверхностями: $z d r s n i t i$ (падение набок), $z d r k n i t i$ (соскальзывание предметов или человека) и zdrseti, объединяющий все вышеперечисленные виды. Если человек поскользнулся (что является периферийной ситуацией в поле падения), то чаще всего употребляется глагол spodrsniti в безличной форме, см. (46) [там же: 195]:

(46) Spodrsnilo mu je na poledeneli cesti.

'Он поскользнулся на обледеневшей дороге'. [носитель]

В рамках словенских глаголов, обозначающих падение с разрушением, происходит четкое разделение на обрушение зданий и мостов (zrušiti se), см (47), и провал опорной поверхности: снега, льда или крыши (udreti se), см. (48). При употреблении последнего глагола невозможна метонимия, подразумевающая провал человека или предмета, находящегося на этой поверхности: «Sneg se je udrl /*Človek se je udrl» 'Снег провалился / *Человек провалился' [там же: 196].

(47) Zidovi so bili v slabem stanju, bali smo se, da se bo stavba kar sama zrušila.

'Стены были в плохом состоянии, мы боялись, что здание само рухнет’. [Dnevnik, 2007]

(48) Streha se je udrla in v nebo se je dvignil velik oblak isker.

'Крыша обрушилась, и в небо поднялся огромный сноп искр'. [Robert Swindells. Zadeti, 2003]

Интересно, что в словенском языке присутствует особый глагол strmoglaviti, связанный, как правило, с падением транспортных средств (49) или других объектов, находящихся в воздухе (50). Ключевую роль здесь играет не большая высота падения, а нестандартная скорость снижения, свидетельствующая о потере контроля и являющаяся сигналом бедствия [там же: 196-197]:

(49) Letalo je strmoglavilo.

'Самолет упал (рухнул)'. [носитель] 
(50) Neki galeb je strmoglavil na tla, otepa s krili in poskusi, da bi vstal. 'Какая-то чайка упала на землю и отряхивается, пытаясь встать'. [Delo, 2002]

Лексемы с корнем -val- фактически отсутствуют в современной словенской системе глаголов падения, поскольку глагол valiti se, как и его сербский когнат (см. Раздел 4.1), близок к исходной семантике 'катиться'.

\section{2. Приставочные дериваты}

В словенской системе глаголов падения сфера применения приставок $o-/ o b$ - является достаточно узкой. На синхронном уровне ее сочетаемость ограничивается возвратным глаголом suti se, от которого образуется приставочный дериват osuti se. Ниже мы рассмотрим особенности его употребления, а также покажем, какими лексическими средствами покрываются в словенском языке те фрагменты концептуального пространства, которые в русском и сербском обслуживаются глаголами падения с приставками *o-/ob-.

\subsection{1. osuti se}

Приставочный дериват osuti se описывает множественное падение частей растений (листьев, лепестков, цветков), см. (51), что соответствует концептуальному значению «тотальное действие» по [Кошелев 2004]:

(51) Jeseni se listje osuje in kmetje pospravljajo svoje pridelke.

'Осенью листва осыпается, и крестьяне собирают свой урожай'. [Dolenjski list, 2007]

Возможен также метонимический перенос (часть $\rightarrow$ целое), проявляющийся в сочетании глагола с наименованиями растений, потерявших листву, плоды или лепестки, см. (52).

(52) Clusijev šopek se je osul, a je še vedno lep.

'Букет горечавки осыпался, но по-прежнему прекрасен'. [Интернет, 2012]

В редких случаях глагол osuti se может обозначать покрытие поверхности какими-либо мелкими объектами (прыщами, звездами), 
аналогично своему сербскому когнату (см. Раздел 4.2) и русскому глаголу обсыпаться (Раздел 3.2), см. (53):

(53) Piksiju so se po vratu osuli sramotni madeži.

'Шею Пикси обсыпали позорные пятна'. [Janja Vidmar. Nimaš pojma. 2006]

Кроме того, весьма частотными являются метафорические употребления данного глагола в значениях:

а) 'миновать, закончиться' (близко к семантике «нового качества» по [Кошелев 2004: 68]):

(54) Tako se je prezgodaj osulo življenje našega dragega prijatelja, pesnika in dobrega človeka...

'Так преждевременно прервалась жизнь нашего дорогого друга, поэта и хорошего человека...'. [Delo, 2002]

(55) »Bila sva nora.« Ljubezen se nama je osula.

‘«Мы были безумцами». Наша любовь канула в Лету’. [Jana Kvas. Mlada obzorja. Književnost 3: učbenik za 3. letnik srednjega poklicnega izobraževanja. 2007]

б) 'снизиться’ («Less is Down»):

(56) Predvsem zaradi nezaposlenosti in inflacije, se je priljubljenost vlade in predsednika $v$ enajstih mesecih kar močno osula.

В первую очередь, из-за безработицы и инфляции, популярность правительства и президента за одиннадцать месяцев сильно снизилась’. [Dnevnik, 1997]

(57) Včasih so na Dneve komedije radi prišli tudi vidni slovenski politiki. $V$ zadnjih letih se je njihov obisk nekoliko osul.

'Когда-то на «Дни комедии» любили приходить известные словенские политики. В последние годы число их визитов несколько сократилось'. [Celjan, 2006]

в) 'покинуть учебное заведение или предприятие':

(58) Vsako leto se v slovenskih srednjih šolah osuje od 8000 do 9000 dijakov.

'Из словенских школ каждый год «вылетает» от восьми до девяти тысяч старшеклассников’. [Dnevnik, 2013] 
Последние два метафорических переноса не зафиксированы в лексикографических источниках, однако фигурируют в корпусе «Gigafida» (10 примеров для б) и 4 для в) во всем корпусе). Ни одна из моделей семантической деривации не встречалась нам ни в русском, ни в сербском материале, а ограниченные употребления глагола osuti se в прямых значениях затрудняют задачу восстановления механизма этих сдвигов. Значение 'миновать, закончиться', по-видимому, связано, в том числе, с семантикой тотального действия (потерей всех листьев, лепестков и проч.) и с общей идеей высыхания, отмирания растения, потерявшего плоды и листву. Метафора снижения уровня, вероятно, возникает за счет наличия в семантике глагола компонента движения вниз. Что касается третьего значения ('покинуть учебное заведение или предприятие'), то можно предположить, что оно профилирует идею открепления частей от целого, присутствующую в исходной семантике глагола.

\subsection{2. odpasti}

В остальных зонах падения приставки $o-/ o b$ - были вытеснены: в частности, на смену устаревшему глаголу opasti пришел odpasti, благодаря префиксу $o d$ - сместивший акцент с множественного падения на отделение части от целого. Сохраняя данное значение в чистом виде (например, в случае отвалившегося у автомобиля колеса), odpasti описывает также множественное падение частей растений, включая плоды (значение «листья»), и отличается значительно более высокой частотностью, чем osuti se, в сочетании с листьями и цветами (746 и 66 вхождений в корпус по сравнению с 10 и 20, соответственно):

(59) Ko jeseni listje odpade, prekrije rastline in jih ščiti čez zimo.

'Когда листва осенью опадает, она покрывает растения и защищает их в течение зимы'. [Naša žena, 2008]

Глагол odpasti также может характеризовать падение сыпучих веществ, например, штукатурки (60), а также зубов и волос (в этом случае речь может идти как о единичном, так и о множественном выпадении объектов, см. (61)). При этом оба этих значения коррелируют с традиционной семантикой приставки $o-/ o b-$ («внешнее действие») и соответствуют значению, которое мы выше условно назвали «штукатурка». Так, например, в сербском языке они оба покрываются глаголом опасти. 
(60) Ob cesti proti Ljubljani namreč stoji stara hiša: šipe so polomljene, omet odpada.

'У шоссе, ведущего в Любляну, стоит старый дом: окна разбиты, штукатурка осыпается'. [Večer, 2001]

(61) Nekdo mi je rekel, da se moram nehati barvati, sicer mi bodo odpadli vsi lasje.

'Кто-то мне сказал, что я должна перестать краситься, иначе у меня выпадут все волосы’. [Nova, 2009]

\subsection{3. Глаголы падения с приставкой $u$ -}

С другой стороны, зону, занимаемую в других анализируемых языках приставкой $o-/ o b-$, в словенском языке покрывает приставка $u$-. Как пишет М. Шекли, словенский префикс $u$ - в сочетании с глаголами движения способен приобретать делативное значение 'вниз': usesti se 'усесться', ugrezniti se ‘погрязнуть', udreti se ‘провалиться’ и т. д. [Šekli 2016: 280]. К числу данных возвратных глаголов, судя по всему, примыкает и usuti se. В отличие от однокоренного глагола с приставкой $o$-, он сочетается как с сыпучими, так и с совокупностями любого рода (не только растительного происхождения). Usuti se обозначает резкое множественное падение, см. (62) и (63), что составляет еще одно его отличие от osuti se (а также от odpasti), который специализируется главным образом на постепенном падении совокупностей, и эта особенность сближает его с сербским осути се.

(62) Na občinstvo se je ob spremljavi cirkuške glasbe usula tona konfetov.

'Под аккомпанемент цирковой музыки на публику посыпалась тонна конфетти'. [Dnevnik, 2001]

(63) Zaradi padavin in začetka jeseni se je te dni na ljubljanske ceste, ulice in pločnike usulo precej odpadajočega listja.

'Из-за осадков и начала осени в эти дни на улицы Любляны высыпало довольно много опавшей листвы'. [Dnevnik, 1998]

C резким характером падения, подразумеваемым глаголом usuti se, связана возможность его употребления по отношению к ливневому дождю (64), что, опять же, характерно для сербского осути се, а также для сербского обрушити се и его русского когната обрушиться. 
(64) Proti jutru je pričelo rositi, potem pa se je usul dež.

'Ближе к утру начал моросить дождь, а потом хлынул ливень'. [Misteriji, 2008]

Данный глагол также сочетается с лексемой plaz 'лавина, оползень', однако не в прямом ее значении. Как правило, речь идет о метафорическом употреблении, переносе на совокупности других объектов, причиняющих физическую боль (камни, стрелы, пули), см. (65). Глагол usuti se в таком случае может обозначать не только непосредственное падение, но и приобретать имплицитный каузативный компонент (ср. русск. обрушиться):

(65) Zaslišal sem, da nekdo teče za menoj 〈...〉 Nekaj sekund pozneje se je name usul plaz kamenja.

'Я услышал, что кто-то за мной бежит. Спустя несколько секунд на меня обрушился град камней’. [Gloss, 2000]

В более абстрактном смысле данное сочетание существительного и глагола может означать внезапное множественное появление обвинений, критики, насмешек и прочих нематериальных субъектов, обычно связанных с проявлением негативной реакции (66). Эта модель семантической деривации также нам уже знакома: она характерна, опять же, для глаголов обрушиться (русск.) и обрушити се (сербск.).

(66) Zaradi izgona Romov se je nanj usul plaz kritik iz vse Evrope.

'Из-за изгнания цыган на него [Н. Саркози] обрушилась волна критики со всей Европы'. [Интернет, 2010]

Как в корпусе «Gigafida», так и в Интернете наблюдается любопытная интерференция глаголов usuti se и vsuti se. Согласно словарной дефиниции, глагол vsuti se обозначает падение внутрь контейнера [SSKJ-2]. Однако по корпусным данным видно, что он как будто перенимает семантику глагола usuti se (заметим, что фонетические различия между этими лексемами в современном словенском литературном языке фактически нейтрализуются). Таким образом, употребление $v s u t i$ $s e$ в значении резкого множественного падения вниз и сопутствующих ему метафорических значениях, ср. (67), (68), - не единичное, а довольно частотное явление (57 вхождений в корпус):

(67) Iz pisma se je vsul sumljiv bel prah.

'Из письма посыпалась подозрительная белая пыль'. [Večer, 2002] 
(68) Plaz očitkov se je vsul z vseh koncev, padale so tako močne ocene, da si jih tudi najboljši scenaristi ne bi mogli izmisliti za kakšno komedijo absurda.

'Волна обвинений обрушилась со всех сторон, появлялись настолько резкие оценки, что даже лучшие сценаристы не могли бы себе их вообразить в какой-нибудь комедии абсурда'. [Hopla, 2009]

Еще один глагол с приставкой $u$-, а именно upasti, в современном языке полностью утратил значение 'упасть'. Однако он по-прежнему актуален в ситуациях снижения уровня поверхности объекта, например, в случае с такими поверхностями, как вода, опухоль или тесто (значение «вода»), см. (69), (70).

(69) Če ne bodo naredili odtočnega kanala, voda ne bo upadla.

'Если не сделают дренажный канал, то вода не спадет'. [Интернет, 2010]

(70) Pri peki testo rahlo upade, če vratca pečice pogosto odpiramo.

'Если мы часто открываем дверцы духовки, тесто при запекании слегка опадает'. [Pepika Levstek, Jožica Štruk. Kuharstvo za vsakogar. 2003]

Наиболее широко глагол upasti используется в качестве метафоры снижения уровня (100 из первых 100 вхождений в «Gigafida»), превосходя в данном сегменте доминантный глагол и повторяя тем самым модель, характерную для сербского опасти:

(71) Ko smo se umaknili in začeli pripravljati novo ploščo, je število pisem upadlo.

'Когда мы ушли в затишье и начали готовить новую пластинку, число писем сократилось'. [Stop, 2003]

(72) Izvoz EUv Rusijo je upadel bolj kot uvoz.

'Экспорт ЕС в Россию снизился больше, чем импорт'. [Finance, 2014]

Ситуации обрушения конструкций, а также падения сверху тяжелых предметов описываются глаголом zrušiti se. Ни приставки o-/ob-, ни активно вытесняющий их формант $u$ - для передачи этих значений не используются.

Таким образом, словенские приставки $o$-/ob- употребляются в зоне падения значительно уже, чем их русские и сербские эквиваленты, 
ограничиваясь лишь значениями множественного падения частей растений («листья», «ягоды») и покрытия поверхности однородными объектами («поверхность»). Все остальные значения, которые в русском и сербском покрываются глаголами падения с приставками $o-/$ об-, в словенском языке передаются с помощью других словообразовательных средств: префиксов $u$ - (и фонетически схожего с ним $v$-), od-, $z$-.

\section{6. Заключение}

Итак, мы рассмотрели особенности сочетаемости глаголов падения

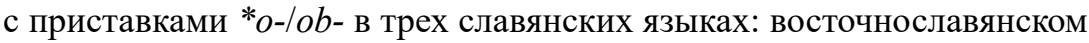
русском и южнославянских сербском и словенском. Несмотря на то, что мы имели дело в основном с когнатами, мы выявили немалое количество различий в их употреблении, что уже не кажется нам удивительным: многие исследования показывают, что изменения в лексике происходят настолько быстро, что близкородственные языки можно включать в лексико-типологические выборки наравне с языками, более далекими друг от друга (см., например, [Rakhilina 2010], [Koptjevskaja-Tamm et al. 2010], [Majid et al. 2015]).

Однако теоретически значимы для нас не столько сами различия, сколько их природа. Так, русские и сербские глаголы падения с приставками о-/об- покрывают, с небольшими оговорками, один и тот же набор значений, несколько по-разному распределяя его между конкретными глаголами. Так что расхождения между русским и сербским в этом фрагменте системы происходят в основном за счет различий в семантике корней, а не приставок: корень -вал- в современном сербском языке, в отличие от русского, не относится к зоне падения, а корень -nад- практически поглощает все те ситуации, в которых в русском языке употребляется -cbln-; тем самым, сербский глагол осути се соответствует скорее русским обсыпаться и обрушиться, чем своему прямому когнату осылаться.

В словенском языке сфера употребления корней глаголов падения в целом очень близка к той, что мы наблюдаем в сербской системе: отсутствует -val-; -pad- вытесняет -sip-. Однако при этом в словенском языке происходит и смещение семантики приставок: $o$-/ob- в разных зонах вытесняется приставками $o d$-, $z$ - и $u$ - (которая, по-видимому, постепенно смешивается с $v$-; заметим, что в сербском языке аналогичные два форманта уже давно совпали в едином $y$-). 
Все эти особенности трех систем можно отразить на семантических картах (см. Pис. 1a-3б) ${ }^{10}$. Из соображений иллюстративности мы повторяем схему несколько раз: концептуальное пространство остается неизменным, но мы поочередно накладываем на него данные всех трех языков, отдельно отображая сферу действия корней, а отдельно - приставок. Важно, что при этом каждый формант занимает неразрывную часть пространства, т. е. принцип смежности, соблюдение которого обязательно при построении семантической карты (см. [Croft 2001]), соблюдается и для корней, и для приставок.

Рисунок 1а. Фрагмент распределения глагольных корней с семантикой падения в русском языке

Figure 1a. Fragment of the distribution of the verbal roots with semantics of falling in Russian

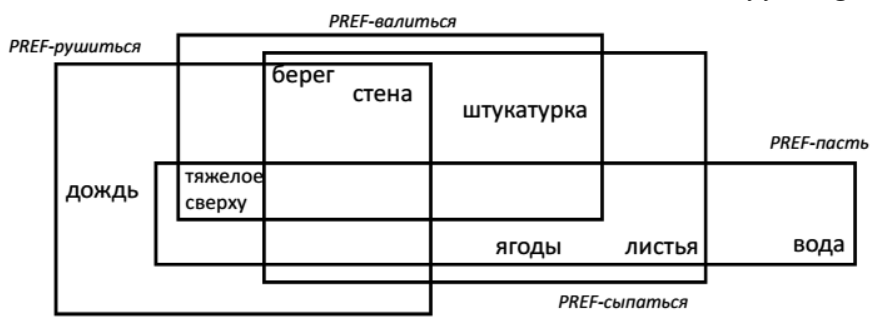

Рисунок 1б. Распределение приставок о-/об- в сочетании с глаголами падения в русском языке

Figure 1b. Distribution of the prefixes o-lob-combined with the verbs of falling in Russian

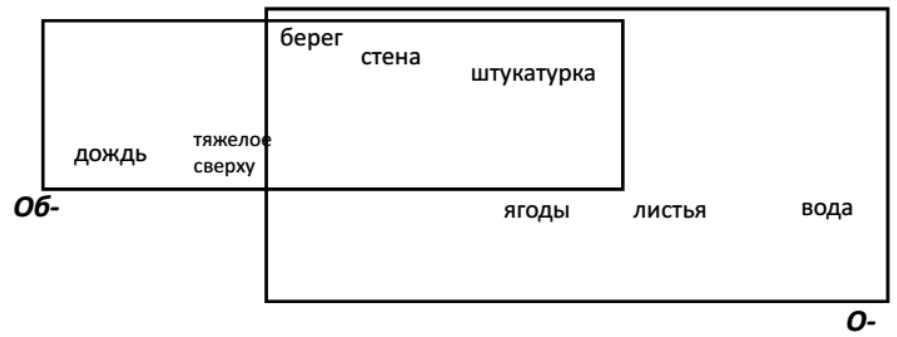

${ }^{10} \mathrm{~B}$ соответствии с методологией MLexT, мы наносим на семантическую карту только прямые значения рассмотренных глаголов. К прямым значениям в данном случае мы относим ситуации буквального, физического падения объектов или их частей. К переносным - все метафоры, а также значение равномерного 
Рисунок 2a. Фрагмент распределения глагольных корней с семантикой падения в сербском языке

Figure 2a. Fragment of the distribution of the verbal roots with semantics of falling in Serbian

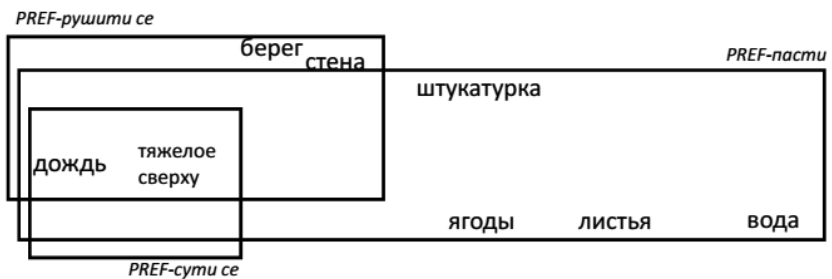

Рисунок 2б. Распределение приставок о-/об- в сочетании с глаголами падения в сербском языке Figure 2b. Distribution of the prefixes o-lob-combined with the verbs of falling in Serbian

06-

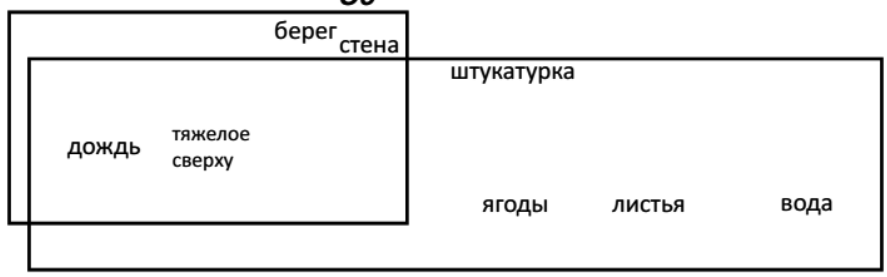

o-

Рисунок 3а. Фрагмент распределения глагольных корней с семантикой падения в словенском языке

Figure 3a. Fragment of the distribution of the verbal roots with semantics of falling in Slovenian

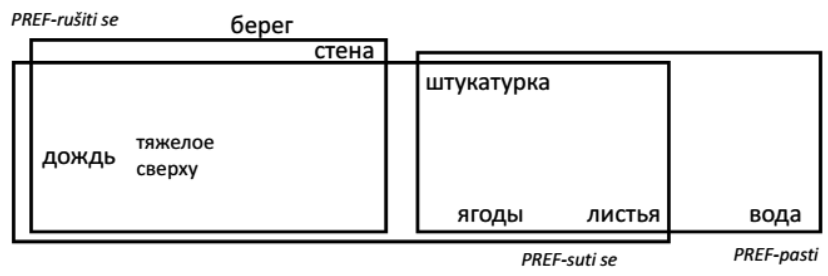

покрытия поверхности однородными объектами («поверхность»), являющееся результатом метонимического сдвига. 
Рисунок 3б. Фрагмент распределения приставок в сочетании с глаголами падения в словенском языке

Figure 3b. Distribution of the prefixes o-/ob-combined with the verbs of falling in Slovenian

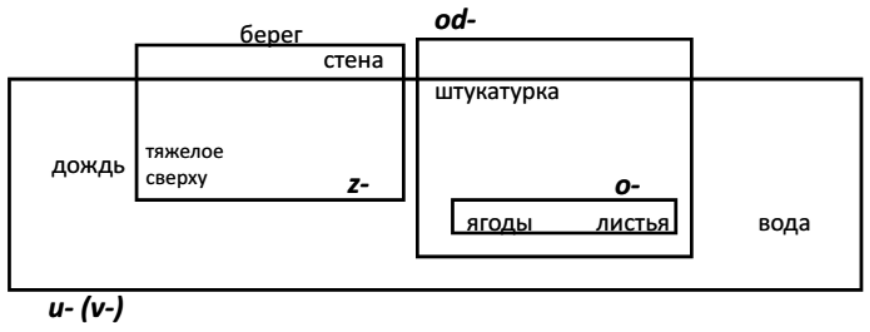

В результате, за счет ограниченной сферы применения приставки $o$-/ob-, на семантической карте словенская часть получилась наиболее плотной и раздробленной. Однако она демонстрирует, каким образом одни приставки могут занимать сферу других, делая при этом акцент на разных аспектах лексического значения. Показательным в данном случае оказывается пример пересечения глаголов osuti se, odpasti и usuti $s e$ в зоне падения однородных объектов («листья», «ягоды»): первый обозначает множественное опадание листьев, лепестков и цветков, второй - как множественное, так и единичное падение плодов, листьев, лепестков, цветков, а третий - резкое множественное падение совокупностей любого типа.

Как известно, в типологии грамматических значений семантические карты отображают семантику грамматических показателей без учета их лексической сочетаемости (см., например, [Haspelmath 1997], [van der Auwera, Plungian 1998] и мн. др.). У словообразовательных формантов сочетаемость значительно более узкая, поэтому для их анализа особенно важно учитывать семантику корней, к которым они присоединяются, - в комплексе с их собственными значениями.

Между моделями метафорических сдвигов в трех языках также наблюдается интересное сходство: одинаковые метафорические употребления характерны не для когнатов, а для глаголов, покрывающих одинаковые точки концептуального пространства. Так, метафору снижения уровня («Less is Down») формируют сербский глагол opasti и словенский upasti, выражающие значение буквального снижения уровня поверхности («вода»), а значение нападения образуется у русского глагола обрушиться, сербского обрушити се и словенского usuti 
$s e$ - по-видимому, потому что все они способны передавать значение внезапного начала стихии («дождь»).

Безусловно, анализ небольшой семантической области всего в трех языках позволяет сделать лишь предварительные выводы; для более обоснованных теоретических заключений необходимо расширение и концептуального пространства, и языковой выборки. Однако комплексный подход, который мы предлагаем, предоставляет такую возможность: единое концептуальное пространство для отображения семантики корней и словообразовательных аффиксов позволяет не только сопоставлять данные близкородственных языков, но и привлекать материалы языков, структурно существенно отличающихся друг от друга. Такое сопоставление мы и считаем самым логичным продолжением нашего исследования.

\section{Литература}

Барыкина и др. 1989 - А. Н. Барыкина, В. В. Добровольская, С. Н. Мерзон. Изучение глагольных приставок. М.: Русский язык, 1989.

Белић 1949 - А. Белић. Савремени српскохрватски књижевни језик. II део: Наука о грађењу речи. Београд: Научна књига, 1949.

ГРЯ - Грамматика русского языка. В 2 т. / Под ред. В. В. Виноградова. М.: Академия наук СССР, 1952-1954.

ГСРЛЯ - Грамматика современного русского литературного языка / Под ред. Н. Ю. Шведовой. М.: Наука, 1970.

Исаченко 1960 - А. В. Исаченко. Грамматический строй русского языка в сопоставлении со словацким. Морфология. Ч. 2. Братислава: Изд-во Словацкой Академии наук, 1960.

Иткин 2007 - И. Б. Иткин. Русская морфонология. М.: Гнозис, 2007.

Кашкин и др. 2015 - Е. В. Кашкин, Д. О. Жорник, А. Н. Закирова, А. Д. Кожемякина, П. С. Плешак. К лексической типологии глаголов падения: данные уральских языков // Д. Ф. Мищенко (ред.). Двенадцатая конференция по типологии и грамматике для молодых исследователей. Тезисы докладов (Санкт-Петербург, 19-21 ноября 2015 г.). С. 41-44.

Кашкин, Плешак 2015 - Е. В. Кашкин, П. С. Плешак. Идеофонические глаголы падения: семантические наблюдения и перспективы типологии // Вестник Воронежского гос. ун-та, Серия: «Лингвистика и межкультурная коммуникация». 2015. № 3. С. 137-142.

Клајн 2002 - И. Клајн. Творба речи у савременом српском језику. Београд; Нови Сад: Ин-т за српски језик Српске академије наука и уметности, Матица српска, 2002. 
Кошелев 2004 - А. Д. Кошелев. О концептуальных значениях приставки о-/об- // Вопросы языкознания. 2004. № 4. С. 68-101.

Кронгауз 1998 - М. А. Кронгауз. Приставки и глаголы в русском языке: семантическая грамматика. М.: Языки русской культуры, 1998.

Кузьменко, Мустакимова 2015 - Е. А. Кузьменко, Э. Г. Мустакимова. Глаголы падения в лексико-типологической перспективе // Е. А. Лютикова, А. В. Циммерлинг, М. Б. Коношенко (ред.). Типология морфосинтаксических параметров. Материалы международной конференции «Типология морфосинтаксических параметров 2015». Вып. 2. М.: Московский пед. гос. ун-т, 2015. С. 149-160.

Кулешова 2016 - М. Л. Кулешова. Глаголы падения в словенском языке: лексико-типологический аспект // Филологические заметки. 2016. Вып. 14. № 2. С. 188-201.

Кюсева, Рыжова 2016 - М. В. Кюсева, Д. А. Рыжова. Особенности выражения локативных значений в кубанском диалекте кабардино-черкесского языка (на примере глаголов падения) // Вестник Воронежского гос. ун-та. Серия: Лингвистика и межкультурная коммуникация. 2016. № 2. Стр. 79-85.

Наумова 2019 - В. А. Наумова. К типологии метафор: глаголы падения: магистерская диссертация. М.: Национальный исследовательский ун-т «Высшая школа экономики», 2019.

Попкова 2019 - Т. А. Попкова. Русские приставочные глаголы падения в лексико-типологической перспективе: выпускная квалификационная работа бакалавра. М.: Национальный исследовательский ун-т «Высшая школа экономики», 2019.

Рахилина, Резникова 2013 - Е. В. Рахилина, Т. И. Резникова. Фреймовый подход к лексической типологии // Вопросы языкознания. 2013. № 2. С. 3-31.

РГ — Русская грамматика. В 2 т. / Под ред. Н. Ю. Шведовой. М.: Наука, 1980.

Стевановић 1964 - М. Стевановић. Савремени српскохрватски језик: граматички системи и књижевнојезичка норма. Београд: Научно дело, 1964.

Толстая 2019 - С. М. Толстая. Праславянские глаголы с префиксом *ob-/o-: морфонология, словообразование, семантика // С. М. Толстая. Мир человека в зеркале языка. Очерки по славянскому языкознанию и этнолингвистике. М.: Индрик. 2019. С. 329-353.

Эндресен 2013 - А. А. Эндресен. Самостоятельные морфемы или позиционные варианты? Морфологический статус приставок о- и об- в свете новых данных: корпус и эксперимент // Вопросы языкознания. 2013. № 6. С. 33-69.

Babić 1986 - S. Babić. Tvorba riječi u hrvatskom književnom jeziku, Nacrt za gramatiku. Zagreb: Djela JAZU, 1986.

Barić et al. 1964 - Barić E., M. Lončarić, D. Malić, S. Pavešić, M. Peti, V. Zečević, M. Znika. Priručna gramatika hrvatskoga književnog jezika. Zagreb: Školska knjiga, 1964.

Będkowska-Kopczyk 2012 - A. Będkowska-Kopczyk. Semantic and grammatical features of o-/ob- in verbs of emotion in Slovene // Jezikoslovlje. 2012. Vol. 13. No. 1. P. 19-39.

Croft 2001 - W. Croft. Radical Construction Grammar: Syntactic Theory in Typological Perspective. Oxford: Oxford University Press, 2001. 
Haspelmath 1997 — M. Haspelmath. Indefinite pronouns. Oxford: Clarendon Press, 1997. Herrity 2000 - P. Herrity. Slovene: A Comprehensive Grammar. London; New York: Routledge, 2000.

Janda, Lyashevskaya 2013 - L. A. Janda, O. Lyashevskaya. Semantic profiles of five Russian prefixes: po-, s-, za-, na-, pro- // Journal of Slavic Linguistics. 2013. Vol. 21. No. 2. P. 211-258.

Kantor 1984 - M. Kantor. The Serbo-Croatian Preverbs o- and ob- // Zbornik Matice srpske za filologiju i lingvistiku, XXVII-XXVIII, 1984-1985. P. 321-325.

Karcevski 1927 - S. Karcevski. Système du verbe russe. Essai de linguistique synchronique. Prague: En Depot a la Librarie, 1927.

Koptjevskaja-Tamm et al. 2010 - M. Koptjevskaja-Tamm, D. Divjak, E. Rakhilina. Aquamotion verbs in Slavic and Germanic: A case study in lexical typology // V. Hasko, R. Perelmutter (eds.). New Approaches to Slavic Verbs of Motion. Amsterdam; Philadelphia: John Benjamins. P. 315-341.

Lakoff, Johnson 1980 — G. Lakoff, M. Johnson. Metaphors We Live By. Chicago, London: University of Chicago Press, 1980.

Leskien 1914 - A. Leskien. Grammatik der serbo-kroatischen Sprache. Heidelberg: C. Winter, 1914.

Majid et al 2015 - A. Majid, F. Jordan, M. Dunn. Semantic systems in closely related languages // Language Sciences. 2015. Vol. 49. P. 1-18.

Maretić 1899 - T. Maretić. Gramatika i stilistika hrvatskoga ili srpskoga književnog jezika. Zagreb: Kugli, 1899.

Rakhilina 2010 - E. Rakhilina. Verbs of rotation in Russian and Polish. // V. Hasko, R. Perelmutter (eds.). New Approaches to Slavic Verbs of Motion. Amsterdam, Philadelphia: John Benjamins. P. 291-314.

Reznikova, Vyrenkova 2015 - T. Reznikova, A. Vyrenkova. Semantics of falling: a cross-linguistic approach // NRU HSE. Working papers by the Basic Research Program: «Linguistics». Moscow. 2015. № 40.

Šekli 2016 - M. Šekli. Pomeni glagoskih prepon v slovenščini // Филологические заметки. 2016. Вып. 14. № 1. С. 273-287.

Toporišič 2000 - J. Toporišič. Slovenska slovnica. Maribor: Založba Obzorja, 2000. van der Auwera, Plungian 1998 - J. van der Auwera, V. Plungian. Modality's semantic map // Linguistic Typology. 1998. Vol. 2. Iss. 1. P. 79-124.

\section{Источники}

МАС - Словарь русского языка: В 4-х т. / Под ред. А. П. Евгеньевой. М.: Русский язык; Полиграфресурсы, 1999.

Ожегов С.И. Словарь русского языка. 9-е изд. М.: Русский язык, 1972.

РСКЈ - Речник српскохрватскога књижевног језика / М. Стевановић, С. Марковић, С. Матић, М. Пешикан. Нови Сад; Загреб: Матица Српска, 1967.

СХРС - И. И. Толстой. Сербско-хорватско-русский словарь. М.: Гос. изд-во иностранных и национальных словарей, 1957. 
SSKJ-2 - Slovar slovenskega knjižnega jezika, druga, dopolnjena in deloma prenovljena izdaja. URL: https://fran.si (дата обращения 21.09.2019).

\section{Корпусы}

НКРЯ - Национальный корпус русского языка. URL: http://www.ruscorpora.ru (дата обращения 21.09.2019).

Gigafida - Gigafida 2.0. Korpus pisne standardne slovenščine. URL: https://viri.cjvt. si/gigafida (дата обращения 21.09.2019).

Korpus savremenog srpskog jezika na Matematičkom fakultetu Univerziteta u Beogradu. URL: http://korpus.matf.bg.ac.rs (дата обращения 21.09.2019).

\section{References}

Babić 1986 - S. Babić. Tvorba riječi u hrvatskom književnom jeziku, Nacrt za gramatiku. Zagreb: Djela JAZU, 1986.

Barić et al. 1964 - E. Barić, M. Lončarić, D. Malić, S. Pavešić, M. Peti, V. Zečević, M. Znika. Priručna gramatika hrvatskoga književnog jezika. Zagreb: Školska knjiga, 1964.

Barykina et al. 1989 - A. N. Barykina, V. V. Dobrovolskaya, S. N. Merzon. Izuchenie glagolnykh pristavok [Studying verbal prefixes]. Moscow: Russkiy yazyk, 1989.

Belić 1949 - A. Belić. Savremeni srpskohrvatski književni jezik. II deo: Nauka o gradjenju reći [The modern Serbo-Croatian literary language. Pt. II: Word formation theory]. Naučna knjiga: Belgrade, 1949.

Będkowska-Kopczyk 2012 - A. Będkowska-Kopczyk. Semantic and grammatical features of o-/ob- in verbs of emotion in Slovene. Jezikoslovlje. 2012. Vol. 13. No. 1. P. 19-39.

Croft 2001 - W. Croft. Radical Construction Grammar: Syntactic Theory in Typological Perspective. Oxford: Oxford University Press, 2001.

Endresen 2013 - A. A. Endresen. Samostoyatelnye morfemy ili pozitsionnye varianty? Morfologicheskiy status pristavok o- i ob- v svete novykh dannykh: korpus i eksperiment [Separate morphemes or allomorphs? Morphological status of the Russian prefixes o- and ob- in the light of the new data: Corpus and experiment]. Voprosy yazykoznaniya. 2013. No. 6. P. 33-69.

GRYA - Grammatika russkogo yazyka [Russian grammar]. In 2 vol. V. V. Vinogradov (ed.). Moscow: Academy of Sciences of USSR Publishing House, 19521954.

GSRLYA - Grammatika sovremennogo russkogo literaturnogo yazyka [N. Yu. Shvedova (ed.). Grammar of the modern Russian literary language]. Moscow: Nauka, 1970.

Haspelmath 1997 - M. Haspelmath. Indefinite pronouns. Oxford: Clarendon Press, 1997. 
Herrity 2000 - P. Herrity. Slovene: A Comprehensive Grammar. London; New York: Routledge, 2000.

Isachenko 1960 - A. V. Isachenko. Grammaticheskiy stroy russkogo yazyka v sopostavlenii so slovatskim. Morfologiya. Ch. 2 [The grammatical structure of the Russian language in comparison with the Slovak. Morphology. Pt. 2]. Bratislava: Slovak Academy of Sciences Publishing House, 1960.

Itkin 2007 - I. B. Itkin. Russkaya morfonologiya [Russian morphonology]. Moscow: Gnozis, 2007.

Janda, Lyashevskaya 2013 - L. A. Janda, O. Lyashevskaya. Semantic profiles of five Russian prefixes: po-, s-, za-, na-, pro-. Journal of Slavic Linguistics. 2013. Vol. 21. No. 2. P. 211-258.

Kantor 1984 - M. Kantor. The Serbo-Croatian Preverbs o- and ob-. Zbornik Matice srpske za filologiju i lingvistiku. XXVII-XXVIII, 1984-1985. P. 321-325.

Karcevski 1927 - S. Karcevski. Système du verbe russe. Essai de linguistique synchronique. Prague: En Depot a la Librarie, 1927.

Kashkin et al 2015 - E. V. Kashkin, D. O. Zhornik, A. N. Zakirova, A. D. Kozhemyakina, P. S. Pleshak. K leksicheskoy tipologii glagolov padeniya: dannye uralskikh yazykov [On the lexical typology of the verbs of falling: data from the Uralic languages]. D. F. Mishchenko (ed.). Twelth Conference on Typology and Grammar for Young Scholars. Abstracts (Saint Petersburg, 19-21 November 2015). P. 41-44.

Kashkin, Pleshak 2015 - E. V. Kashkin, P. S. Pleshak. Ideofonicheskie glagoly padeniya: semanticheskie nablyudeniya i perspektivy tipologii [Russian verbs of falling derived from ideophones: semantic observations and typological perspectives]. Vestnik Voronezhskogo gosudarstvennogo universiteta. Series: Lingvistika i mezhkulturnaya kommunikatsiya. 2015. No. 3. P. 137-142.

Klajn 2002 - I. Klajn. Tvorba reći u savremenom srpskom jeziku [Word formation in the modern Serbian language]. Belgrade, Novi Sad: Institute for the Serbian Language of Serbian Academy of Sciences and Arts, Matica srpska, 2002.

Koptjevskaja-Tamm et al. 2010 - M. Koptjevskaja-Tamm, D. Divjak, E. Rakhilina. Aquamotion verbs in Slavic and Germanic: A case study in lexical typology. V. Hasko, R. Perelmutter (eds.). New Approaches to Slavic Verbs of Motion. Amsterdam; Philadelphia: John Benjamins. P. 315-341.

Koshelev 2004 - A. D. Koshelev. O kontseptualnykh znacheniyakh pristavki o-/ob[On the conceptual meanings of the prefix o-/ob-]. Voprosy yazykoznaniya. 2004. № 4. P. 68-101.

Krongauz 1998 - M. A. Krongauz. Pristavki i glagoly v russkom yazyke: semanticheskaya grammatika [Prefixes and verbs in Russian language: semantic grammar]. Moscow: Yazyki russkoy kultury, 1998.

Kuleshova 2016 - M. L. Kuleshova. Glagoly padeniya v slovenskom yazyke: leksiko-tipologicheskiy aspekt [Slovenian verbs of falling: a lexical typological aspect]. Filologicheskie zametki. 2016. Vol. 14. No. 2. P. 188-201.

Kuzmenko, Mustakimova 2015 - E. A. Kuzmenko, E. G. Mustakimova. Glagoly padeniya $\mathrm{v}$ leksiko-tipologicheskoy perspektive [Verbs of falling from lexical typological perspective]. E. A. Lyutikova, A. V. Zimmerling, M. B. Konoshenko (eds.). 
Typology of morphosyntactic parameters. Proceedings of the international conference «Typology of morphosyntactic parameters 2015». Vol. 2. Moscow: Moscow Pedagogical State University Press, 2015. P. 149-160.

Kyuseva, Ryzhova 2016 - M. V. Kyuseva, D. A. Ryzhova. Osobennosti vyrazheniya lokativnykh znacheniy v kubanskom dialekte kabardino-cherkesskogo yazyka (na primere glagolov padeniya) [Verbs with the semantics of falling and locative meanings in Kuban Kabardian]. Vestnik Voronezhskogo gosudarstvennogo universiteta. Series: Lingvistika i mezhkulturnaya kommunikatsiya. 2016. No. 2. P. 79-85.

Lakoff, Johnson 1980 - G. Lakoff, M. Johnson. Metaphors We Live By. Chicago; London: University of Chicago Press, 1980.

Leskien 1914 - A. Leskien. Grammatik der serbo-kroatischen Sprache. Heidelberg: C. Winter, 1914.

Majid et al 2015 - A. Majid, F. Jordan, M. Dunn. Semantic systems in closely related languages. Language Sciences. 2015. Vol. 49. P. 1-18.

Maretić 1899 - T. Maretić. Gramatika i stilistika hrvatskoga ili srpskoga književnog jezika. Zagreb: Kugli, 1899.

Naumova 2019 - V. A. Naumova. K tipologii metafor: glagoly padeniya: magisterskaya dissertatsiya [On the typology of metaphors: verbs of falling: master thesis]. Moscow, National Research University Higher School of Economics, 2019.

Popkova 2019 - T. A. Popkova. Russkie pristavochnye glagoly padeniya v leksiko-tipologicheskoy perspektive: vypusknaya kvalifikatsionnaya rabota bakalavra [Russian prefixed verbs of falling from the lexical typology perspective: bachelor thesis]. Moscow, National Research University Higher School of Economics, 2019.

Rakhilina 2010 - E. Rakhilina. Verbs of rotation in Russian and Polish. V.Hasko, R. Perelmutter (eds.). New Approaches to Slavic Verbs of Motion. Amsterdam; Philadelphia: John Benjamins. P. 291-314.

Rakhilina, Reznikova 2013 - E. V. Rakhilina, T. I. Reznikova. Freymovyy podkhod k leksicheskoy tipologii [A Frame-based methodology for lexical typology]. Voprosy yazykoznaniya. 2013. No. 2. P. 3-31.

Reznikova, Vyrenkova 2015 - T. Reznikova, A. Vyrenkova. Semantics of falling: a cross-linguistic approach. NRU HSE. Working papers by the Basic Research Program: «Linguistics». Moscow. 2015. No. 40.

RG - N. Yu. Shvedova (ed.). Russkaya grammatika [Russian grammar]. In 2 vol. Moscow: Nauka, 1980.

Stevanović 1964 - M. Stevanović. Savremeni srpskohrvatski jezik: gramatički sistemi i književnojezička norma [The modern Serbo-Croatian language: grammar systems and literary language norm]. Belgrade: Naučno delo, 1964.

Šekli 2016 - M. Šekli. Pomeni glagoskih prepon v slovenščini. Filologicheskie zametki. 2016. Vol. 14. No. 1. P. 273-287.

Tolstaya 2019 - S. Tolstaya. Praslavyanskie glagoly s prefiksom *ob-/o-: morfonologiya, slovoobrazovanie, semantika [Proto-Slavic verbs with the prefix *ob-/o-: morphonology, word formation, semantics]. S. Tolstaya. The World of Man in the Mirror of Language. Essays on Slavic linguistics and ethnolinguistics. Moscow: Indrik, 2019. P. 329-353. 
Toporišič 2000 - J. Toporišič. Slovenska slovnica. Maribor: Založba Obzorja, 2000. van der Auwera, Plungian 1998 — van der J. Auwera, V. Plungian. Modality's semantic map. Linguistic Typology. 1998. Vol. 2. Iss. 1. P. 79-124.

\section{Sources}

MAS - Slovar russkogo yazyka [Dictionary of the Russian language]: in 4 vol. A. P. Yevgeneva (ed.). Moscow: Russkiy yazyk; Poligrafresursy, 1999.

Ozhegov - S. I. Ozhegov. Slovar russkogo yazyka [Dictionary of the Russian language]. $9^{\text {th }}$ edition. Moscow: Russkiy yazyk, 1972.

RSKJ - Rečnik srpskohrvatskoga kniževnog jezika [Dictionary of the Serbian language]. M. Stevanović, S. Marković, S. Matić, M. Pešikan. Novi Sad; Zagreb: Matica Srpska, 1967.

SKHRS - I. I. Tolstoy. Serbsko-khorvatsko-russkiy slovar [Serbo-Croatian-Russian dictionary]. Moscow: State Publishing House of Foreign and National Dictionaries, 1957.

SSKJ-2 - Slovar slovenskega knjižnega jezika, druga, dopolnjena in deloma prenovljena izdaja. Available at: https://fran.si (accessed on 21.09.2019).

\section{Corpora}

NKRYA - Natsionalnyy korpus russkogo yazyka [Russian national corpus]. Available at: http://www.ruscorpora.ru (accessed on 21.09.2019).

Gigafida - Gigafida 2.0. Korpus pisne standardne slovenščine. Available at: https://viri.cjvt.si/gigafida (accessed on 21.09.2019).

Korpus savremenog srpskog jezika na Matematičkom fakultetu Univerziteta u Beogradu. Available at: http://korpus.matf.bg.ac.rs (accessed on 21.09.2019). 